\title{
Entre Arcadia y Utopía: el país imaginado de las Soledades de Góngora ${ }^{1}$
}

\author{
Mercedes Blanco \\ Université Paris-Sorbonne \\ citrine@club-internet.fr
}

Recepción: 10/06/2014, Aceptación: 30/06/2014, Publicación: 17/12/2014

\begin{abstract}
Resumen
El artículo, partiendo de un paralelo entre los países imaginarios representados en la Arcadia de Sannazaro (1504) y la Utopia de More (1515), y teniendo en cuenta los dos paradigmas inducidos por estas obras en la literatura anterior y posterior, sostiene que un siglo más tarde, Luis de Góngora inventa en las Soledades un país imaginario que participa de ambos. El poema cuenta una historia ambientada en en una zona rural idealizada, según el modelo de Arcadia. Propone sin embargo a su manera una óptima constitución de la república o utopía, un modelo de felicidad colectiva hecho posible por la elisión de cuando en la sociedad real de entonces implicaba alienación y represión. Esta representación en un lenguaje altamente culto y complejo no es meramente poética, sino que responde a propuestas políticas contemporáneas. Por un lado, repercute ideas de reforma similares a las que sostuvo el famoso humanista amigo de Góngora, Pedro de Valencia. Por otro lado, se presenta como alternativa crítica a ciertas utopías de inspiración franciscana, de cariz mesiánico y místico, como las que el navegante Pedro Fernández de Quirós vinculaba a su proyecto de empresa colonial ibérica en zonas australes del Pacífico.
\end{abstract}

Palabras clave

Arcadia; Utopía; Góngora; Pedro de Valencia; reformismo político en la España de los Austrias

1. Maria Zerari, Jaime Galbarro, Florence d'Artois, Jean-Michel Morel y Jesús Ponce Cárdenas han tenido la gentileza de mejorar este ensayo con sus correcciones y sugerencias. Conste aquí mi gratitud a todos ellos. 


\begin{abstract}
Between Arcadia and Utopia: the Imagined Country in Góngora's Soledades

As a basis for its argumentation, the article sketches a parallel between the imaginary countries represented in Sannazaro's Arcadia (1504) and More's Utopia (1515). Taking into account the two paradigms induced by these masterpieces in previous and posterior literature, it claims that a century later Luis de Góngora designs in the Solitudes an imaginary country that holds something of both models. The poem tells a story set in a idealized rural region, along the lines of Arcadia. And at the same time it reflects an optimal constitution of the republic or utopia, a model of collective happiness made possible by the elision of all elements of social reality that involve misery and loss of freedom. This representation in a highly learned and complex language is not merely poetic, but responds to contemporary political proposals. On the one hand it echoes reform ideas similar to that held by a famous Góngora's friend, the humanist Pedro de Valencia. On the other hand it suggests the rejection of certain contemporary messianic utopias, such as those that the navigator Pedro Fernandez de Quirós linked to his project of Iberian colonial enterprise in southern areas of the Pacific.
\end{abstract}

Keywords

Arcadia; Utopia; Góngora; Pedro de Valencia; political reformism in Habsbourg Spain

Los nombres de Arcadia y de Utopía fueron primero topónimos; luego tradiciones literarias que afloran en una gran variedad de textos ${ }^{2}$; últimamente, se refirieron a conceptos políticos y estéticos. El impulso decisivo para este proceso de generalización procedió de dos breves obras maestras cuya invención se alzaría al rango de arquetipo: la Arcadia del noble napolitano Jacopo Sannazaro, publicada en Nápoles en $1504^{3}$, compuesta de doce prosas que alternan con doce églogas en verso; y la obra del canciller inglés Thomas More, Deque op-

2. A partir del libro de Thomas More, Deque optimo reipublicae statu deque nova insula Utopia, no sólo se incluyeron en el género «utopía» una serie de libros posteriores e inspirados por él, sino que se construyó retrospectivamente una tradición antigua de obras utópicas o con partes utópicas, en la que se clasificaron libros tan distintos como la República de Platón, las Etiópicas de Heliodoro, La historia verdadera de Luciano y los resúmenes por Diodoro de Sicilia de obras perdidas de Evémero y Iámbulo. Véase Futre Pinheiro (2006) y Winiarczyk (2011).

3. Ya en 1502 había salido una edición no autorizada por Sannazaro y plagada de errores en Venecia. Véase la introducción a Sannazaro (2004). 
timo reipublicae statu deque nova insula Utopia, diálogo que enmarca el relato pseudo-testimonial de un viaje a un país imaginario, impreso en Lovaina en 1516. Ambas pertenecen a un "otoño del humanismo», destinado a dar frutos durante toda la Edad Moderna. Ambas alcanzaron fama inmediata y tuvieron amplísimas repercusión y descendencia ${ }^{4}$.

El argumento, reducido a esquema, es parecido. Alguien viaja a una región que comparte con lo soñado su falta de conexión practicable con la experiencia ordinaria y regresa de este viaje con ánimo de narrar lo visto en este país. Sincero, gentilhombre napolitano acongojado por una decepción amorosa, se refugia en la remota Arcadia y luego vuelve a Nápoles recorriendo redes de cavernas submarinas de donde nacen todos los ríos, y que enlazan el río Alfeo de Arcadia con el Sebeto de Campania ${ }^{5}$. El portugués Rafael Hythlodeus, «Ulises» moderno que navegó con Amerigo Vespucci, le cuenta sus viajes por mares desconocidos a Thomas More, embajador del rey de Inglaterra en Flandes. Lo más asombroso de cuanto vio Hythlodeus a lo largo de su periplo es la isla llamada Utopía, cuyo gobierno y costumbres son minuciosamente descritos en el último de los dos libros que componen la obra. Hythlodeus sitúa en la inmensidad ignota de los océanos del hemisferio Sur esta república insular dotada del mejor régimen posible (optimus reipublicae status). Con humor juguetón aprendido en Luciano, More y sus amigos fingen que sólo una pequeña avería de la comunicación, en vías de resolverse, impide que sepamos por ahora la localización de este fénix de las ínsulas.

Una y otra obra eliminan del mundo imaginario que crean o recrean los componentes más opresivos de la vida social en la Europa de su tiempo: castas de

4. Sobre la influencia de la Arcadia de Sannazaro en Europa, la bibliografía es amplísima y dispersa. Véase para España, Reyes Cano (1973), Tateo (1993), Cañas Gallart (2013); y, para Garcilaso, Gargano (2002) y Gargano (2009). Para Europa, puede consultarse Torraca (1928); Longeon (1980); Kennedy (1983). Sobre la recepción de la Utopía de More, estudiada a través de los paratextos de las traducciones a diferentes lenguas europeas, véase Cave (2011). En lo que respecta específicamente a España y al mundo hispánico, López Estrada (1980 y 1992); Gómez (2001). Para nuestro propósito interesa recordar que se hicieron al menos dos traducciones de la Utopía en la España del Siglo de Oro. La más temprana, desconocida hasta que en 1992 López Estrada la encontrara por indicación de Stefano Arata, sigue desgraciadamente inédita y el manuscrito que la contiene, procedente de la colección Gondomar, se conserva en la Real Biblioteca, bajo la signatura II/1087_B. Véase López Estrada (1992). No hay indicios paratextuales que permitan precisar el autor como tampoco la fecha, anterior a la muerte de More en 1535. Hubo que esperar más de un siglo a la segunda traducción castellana cuyo autor, Jerónimo de Medinilla y Porres, la hizo imprimir en 1639 en Córdoba, ciudad de la que era entonces corregidor. La obra iba escudada por un aparato de aprobaciones excepcionales en número y amplitud, entre las cuales destaca la de Francisco de Quevedo, que despertó la curiosidad de López Estrada (1965). Sería muy deseable que alguien profundizara más en estas traducciones y en sus circunstancias.

5. Arcadia prosa XII, Sannazaro (2004: 239). Esa geografía imaginaria de ríos subterráneos que unen Italia con Grecia es invención virgiliana (Égloga X y Geórgicas IV) a partir del mito de Alfeo y Aretusa, en que el dios fluvial se desplaza desde Grecia hasta Sicilia persiguiendo a la ninfa amada, para culminar como cauce acuático nuevo en el paraje insular mediterráneo. La invención es brillantemente recuperada por el escritor napolitano. Véase Vecce (2013: 11-12). 
señores y vasallos, trabajo como penalidad y servidumbre, sumisión de las íntimas creencias a un aparato eclesiástico, riqueza ostentosa acaparada por muy pocos e indigencia para la mayoría. El viaje ficticio adentra a los lectores en un país imposible y fantástico pero capaz de convertirse en acicate de una reforma interior, de una curación del alma, y tal vez en estímulo de una reforma política o religiosa.

Esbozaremos a partir de esta base común un paralelo entre ambas obras, sin olvidar que se trata de creaciones con planteamientos heterogéneos y tal vez antitéticos. Con ese trasfondo, nos resultará más fácil establecer lo que constituye la tesis de nuestro estudio: cómo y por qué un siglo más tarde, las Soledades (1613-1617) de Luis de Góngora, contando una historia que transcurre en unas «soledades» rurales idealizadas, según el patrón de la Arcadia, no dejan de proponer a su modo una óptima constitución de la república o utopía, un modelo de felicidad colectiva hecho posible por la elisión de los aspectos represivos y alienantes de la vida social. Esta representación en un elaboradísimo lenguaje no es meramente "poética», si con ello se entiende ajena a cualquier empeño real, sino que responde a propuestas políticas contemporáneas del poema; de modo positivo aunque autónomo y sui generis, a ideas de reforma similares a las que sostuvo el famoso humanista amigo de Góngora, Pedro de Valencia; de modo negativo, a ciertas «utopías» de inspiración franciscana y de cariz mesiánico y místico, como las que el navegante Pedro Fernández de Quirós vinculaba a su proyecto de empresa colonial ibérica en las islas del Pacífico Sur y en un supuesto continente austral.

\section{Arcadia y Utopía frente a frente}

El nombre Arcadia se refiere a una región montañosa situada en el corazón del Peloponeso, que se creía protegida por su aislamiento y su misma pobreza, y que, ajena a las turbulencias de la historia griega, habría gozado de una paz inalterable. Esta antigua creencia se recuerda en uno de los textos más influyentes de la pastoral dramática de finales del Renacimiento: Il Pastor fido de Guarini (1589-1602). El poeta confía el papel de prologuista al ilustre río de Arcadia, el Alfeo. Destaco unos versos de esta figura en la traducción castellana de Cristóbal Suárez de Figueroa:

¡Oh dulce engendradora, y de tu hijo

reconocida, Arcadia!,

reconoce asimismo a tu querido

y no menos que tú famoso Alfeo.

Estos son los contornos,

éstos los verdes prados y las selvas

donde vivió y murió el valor antiguo:

a sólo este distrito

pienso se retirase el siglo de oro,

del férreo mundo huyendo y de su gente. 


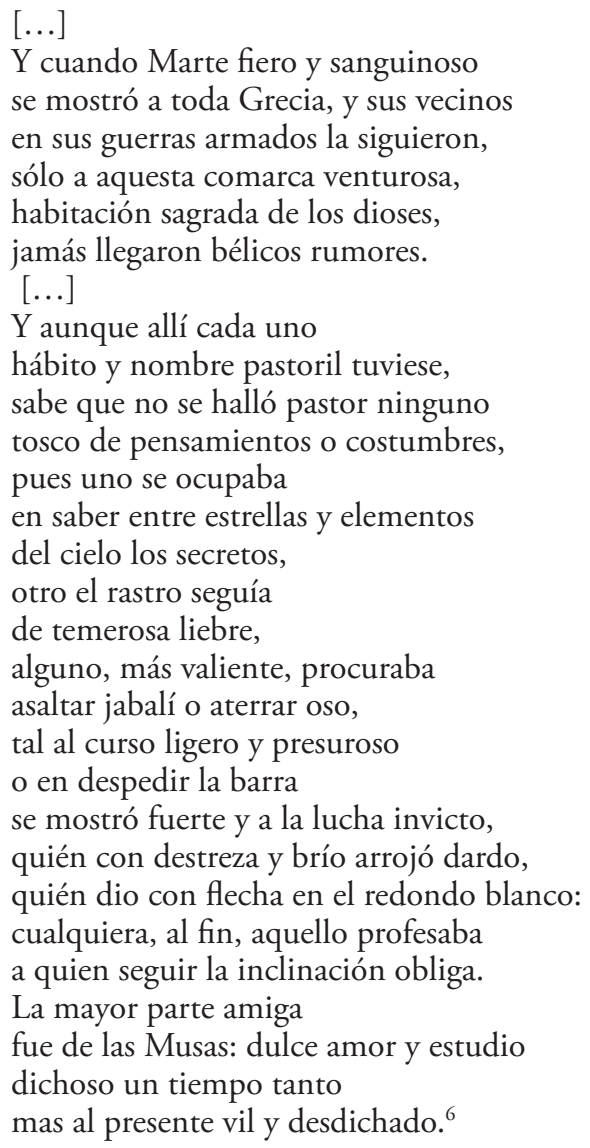

Arcadia, en opinión corriente pero no unánime entre los especialistas de Virgilio, ya había sido elevada a la categoría de mito en las Bucólicas ${ }^{7}$. Lo innegable es que Sannazaro le confiere a Arcadia un sello y una dignidad virgilianas, y que su país reinventado se volverá un territorio de la imaginación literaria y artística europea, un "paisaje espiritual», como lo llamó Bruno Snell. En Arcadia sólo viven rústicos pastores y no hay entre ellos hombres armados y otros inermes, ricos y pobres, señores y siervos, aunque sí hay rastro de la presencia, en un

6. Suárez de Figueroa (1602: 22-23). Se trata de la primera de las dos traducciones de Guarini publicadas por este autor, la cual vio la luz en Nápoles en 1602.

7. Al menos, así lo han visto muchos, siguiendo un famoso ensayo de Snell (1945). Sin embargo hay quien piensa que el inventor de esa región espléndida y melancólica llamada Arcadia, compartida por la literatura y el arte desde el Renacimiento hasta el romanticismo, no es Virgilio sino Sannazaro, Así, según Robert Jenkyns, su atribución a Virgilio es sólo el resultado de una lectura retrospectiva de las Bucólicas, inducida por la Arcadia de Sannazaro y su posteridad. Véase Jenkyns (1989: 27), que resume la discusión sobre la Arcadia virgiliana. 
pasado no muy lejano o en los umbrales del mundo visible, de seres superiores e inmortales, de dioses, de sátiros, de faunos y de ninfas. Ciertamente las cosas son menos sencillas en el complejo librito del gran poeta napolitano que en la Arcadia convencional del prólogo de Guarini: la Arcadia de Sannazaro aparece invadida y contaminada por aquellos males sociales (los de la Nápoles aragonesa, los de la pequeńa nobleza a la que pertenece el autor) para los que suponía en principio un inviolable refugio ${ }^{8}$. Una gran disparidad en este sentido se da entre las prosas y los versos, y entre las distintas prosas, escritas en distintas fases de la larga gestación de la obra. Sin embargo, aunque la protección que ofrece contra la opresión y la injusticia se revele intermitente y frágil, esta Arcadia no deja de definirse como un santuario del goce verdadero e inocente, de la naturaleza intacta, de la amistad sincera: si Arcadia se revela al fin «imposible» como afirma Enrico Fenzi, es precisamente porque se define por una felicidad colectiva que todo desmiente en la historia real, y no sólo en la experiencia histórica del autor?

Los árcades cuidan sus rebaños, pero esta poco exigente tarea no impide que se entreguen a actividades liberales: una modesta caza realizada a modo de juego, rituales en honor a los dioses y a los muertos, competiciones atléticas, fabricación de unos pocos objetos delicados y elegantes. Pero ante todo les ocupa lo que llamaría Guarini el trato de las Musas: observación de los astros, poesía, música, conversación sobre temas elevados.

Algo comparable sucede a los ciudadanos de Utopía, entre quienes no hay diferencias de riqueza, aunque sí de autoridad. Su vida, sometida a un programa regular y medido por los relojes, prevé seis horas de trabajo diario, ocho de sueño, dos empleadas en comidas, una en paseos y jardines. Las que sobran deben gastarse en la dedicación liberal —no por no profesional menos seria— a las letras y a la filosofía, y de modo prioritario a esa parte de la filosofía que consiste en estudiar la naturaleza, con ánimo de admirar la obra divina y de hallar técnicas capaces de mejorar la vida humana. Se basan estas disposiciones en el principio afirmado por los griegos de que la felicidad reside en la contemplación o inteligencia de las $\operatorname{cosas}^{10}$. En la versión modernizada y nada eremítica de la contemplación propia de

8. En varios pasajes dispersos, asoman estos males de Arcadia, lobos impunes y pastores expoliados y humillados, a los que está dedicada enteramente la égloga VI, la última égloga juvenil inserta en el Libro pastorale, en que dialogan Serrano y Opico. Véase Sannazaro (2014, 153): "L'allegoria si riferisce certamente alla Napoli aragonese, di cui Sannazaro testimonia la crisi [...] Ma al di là del contesto storico e politico, la voce di Opico si eleva a un livello generale, universale: è la malinconia per l'infanzia perduta dell'umanità, per una condizione di armonia tra uomo e natura, ancora incorrotta...".

9. Cae fuera de los objetivos de este ensayo citar y menos resumir la amplia y brillante bibliografía dedicada al significado político de la Arcadia de Sannazaro. Baste, para lo que nos toca, referirnos a un reciente e importante trabajo, que toma debidamente en cuenta la anterior discusión acerca del tema: Fenzi, 2009.

10. Según Aristóteles, Política, VIII, 3, 3, la naturaleza humana tiene por último fin el goce noble del ocio (definido como disfrute sereno de la inteligencia y otros dones del espíritu) y todas las 
Utopía, se deduce de este principio el derecho para todos de disponer de tiempo y fuerzas para cultivar su espíritu, no solitaria sino colectivamente, en actividades académicas en el sentido lato de la palabra. Los utopianos comparten, de modo equitativo aunque no estrictamente igual, tanto el trabajo agrícola y fabril destinado a cubrir las necesidades materiales y a procurar todas las formas de placer inofensivo y honesto ${ }^{11}$, como por otro lado las letras y la filosofía.

Pese a ello, las diferencias entre estos dos países imaginarios y entre los libros que los inventan o reinventan saltan a la vista. La Arcadia de Sannazaro contribuye a transmitir al Renacimiento internacional del siglo XVI el legado poético del humanismo italiano: ficción ambientada en un territorio incierto, como en suspenso entre la contemporaneidad más estricta y la recreación de la antigüedad pagana; una marquetería de «imitaciones» de los clásicos griegos y latinos y de los nuevos clásicos toscanos, Petrarca y Boccaccio ${ }^{12}$; un modelo de elegancia en lengua vernácula, hecha de falsas naturalidad y modestia, y de

actividades deben organizarse para liberar un margen de ocio lo más amplio posible. El principio aparece como argumento central en Utopia, libro II, De artificiis: «Neque enim supervacaneo labore cives invitos exercent magistratus, quandoquidem eius reipublicae institutio hunc unum scopum in primis respicit: ut quoad per publicas necessitates licet, quam plurimum temporis ab servitio corporis ad animi libertatem cultumque civibus universis asseratur. In eo enim sitam vitae felicitatem putant». Así lo traduce Medinilla y Porres (1637: fol. 10): «Porque los Magistrados no ocupan a los Ciudadanos en trabajos inútiles y superfluos, pues que la institución y motivo desta República principalmente atiende sólo a este fin, a que satisfechas las necesidades públicas, en cuanto ellas dieren lugar, lo más del tiempo que sobra a los empleos serviles, se reduzca a que los Ciudadanos gozen de la libertad, y contemplación del ánima, porque en esto juzgan consiste la verdadera felicidad.» Modernizamos la grafía.

11. Véase acerca de ello Surtz: 1957. Es uno de los clásicos sobre el tema de Utopía debido a Edward Surtz, gran especialista jesuita de Thomas More y coautor, con Jack H. Hexter, de la edición de Yale (1965).

12. La imitación en Sannazaro sigue principios eclécticos y no puristas (es decir, ciceronianos en prosa y virgilianos en verso) como lo muestra el análisis intertextual de sus varios libros y lo declara una famosa carta a Antonio Seripando. Allí defiende con vehemencia que no hay que adoptar de modo exclusivo la lengua y el estilo de Virgilio, ni de ningún otro autor. Véase la introducción de Gérard Marino a Sannazaro (2004: XLVI-XVII). Véase también la introducción de Vecce (2013: 20): «Tra gli anni settanta e ottanta del Quattrocento, un intensa formazione umanistica latina (e parzialmente anche in greco) lo aveva avvicinato ai testi classici, attentamente schedati in quadernini e zibaldoni di cui resta, di questa fase giovanile, un repertorio antiquario che rivela l'affinità d'orizzonti del giovane letterato con le guide culturali del suo tempo, Pontano a Napoli, e a Roma Pomponio Leto e la sua cerchia, con lideale della ricostruzione integrale della vita e dei costumi degli antichi, su testi como i "Fasti" di Ovidio, il "De lingua latina" di Varrone, la "Storia naturale" di Plinio il Vecchio, Seneca, Marziale con il commento di Domizio Calderini, gli storici; e poi naturalmente i poeti: Virgilio, Ovidio, Orazio, Claudiano, Lucrezio (una presenza sotterranea ma importante, fonte di una venatura epicurea che non scomparirà nemmeno nel poema cristiano del 'De partu Virginis'), Stazio, gli elegiaci, Properzio e Tibullo, i bucolici minori Calpurnio e Nemesiano; fra gli autori greci, Teocrito (ma anche Mosco e Bione) e Omero. Grazie a questo ricco bagaglio d'esperienze, Sannazaro ha conquistato la piena intelligenza dell'elemento costitutivo della bucolica classica, l'arte allusiva, la scrittura di secondo grado (una poesia fatta di poesia, la raffinata composizionelcombinazione di 'mosaici' (secondo la metafora cara a Leon Battista Alberti) intarsiati di tessere derivate dagli autori antichi, e l'ha applicata sistematicamente ai testi in volgare scelti come modelli (dominanti, ma non esclusivi) per il libro pastorale, Boccaccio per la prosa e Petrarca per la poesia [...]». 
verdaderos refinamiento y erudición, tanto en prosa como en verso. De modo opuesto y complementario, la Utopía de More se nos presenta como una breve suma del humanismo nórdico de signo evangélico y un modelo de latín ecléctico y copioso, vivo aunque docto, nada purista y que puede manejarse para decir cosas en que no pensó Cicerón ${ }^{13}$.

La pastoral de Sannazaro tiene un carácter anticuario que desde Italia mira hacia la religión romana y al mito primitivista tan caro a los poetas de la Edad de Augusto $^{14}$. La posible felicidad de Arcadia, aunque siempre traspasada por un angustioso sentimiento de pérdida y de nostalgia (para el caballero napolitano, la de un tiempo anterior a la crisis política, a la guerra y al exilio que ensombrececieron los años finales del siglo XV y los primeros del siguiente), está basada en un principio estético afirmado en el prólogo. El sumo grado del deleite y de la belleza residen no en las sofisticaciones del lujo, en las complicaciones del arte, en la riqueza de los materiales preciosos, sino en lo más común, antiguo y eterno de una naturaleza inviolada, representada por los altos árboles en los montes, por el canto de los silvestres pájaros en los bosques solitarios, por las fuentes surgiendo de las rocas: « $E c h i$ dubita che più non sia alle umane menti aggradevole una fontana che naturalmente esce da le vive pietre, attorniata di verdi erbette, che tutte le altre ad arte fatte di bianchissimi marmi, risplendenti di vivo oro ?., ${ }^{15}$. La modesta fuente que naturalmente mana de las vivas piedras simboliza lo que brota por primera vez, una infancia del mundo (a la que parecen responder los diminutivos que frecuenta Sannazaro como erbetta, semplicetto, fioretti). Estas menudas delicadezas alternan con la majestad arcana de los lugares sublimes, las ásperas cumbres y tenebrosas cavernas, lugares vedados a los hombres y a las bestias, propicios a los rituales y a la magia. A la cándida fuente del prólogo, con sus hierbecillas, responde, en la prosa $\mathrm{X}$, la garganta subterránea en que nace «il terribilissimo fume», para enseguida sumergirse en una inmensa vorágine cercada de «horrendos estrépitos, causados

13. Véase Prévost (1978: CCXI-CCXXII), «La langue latine de l'Utopie». Prévost se apoya en varios trabajos anteriores, especialmente en la edición de la Utopía por Marie Delcourt (París, 1936 y Ginebra, 1983).

14. Véase Fabre-Serris (2008).

15. Esta frase de Sannazaro parece servir casi de plantilla a un fragmento de los Capitoli de Tansillo: "Quanto più piace una fontana pura, / la qual senza saper ferri nè mastri / cade tra tufi in una valle oscura, I che quella ch'elevata sui pilastri / in un giardin che abbia lucente il suolo / corre per sopra i marmi e gli alabastri! / A me ristora, quando ho noia o duolo, / piu che cento giardini, una campagna». El meollo de la comparación (fuente natural / fontana artística) que establecen Sannazaro o Tansillo, contraponiendo el atractivo de la naturaleza y el del artificioso jardín, constituirá después la materia del soneto II, 12, que Medrano dirige a Arguijo: «Cansa la vista el artificio humano, / cuanto mayor, más presto. La más clara / fuente y jardín compuestos dan en cara / que nuestro ingenio es breve y nuestra mano. / Aquel, aquel descuido soberano / de la Naturaleza, en nada avara, / con luenga admiración suspende y para / a quien lo advierte con sentido sano. / Ver cómo corre eternamente un río, / cómo el campo se tiende en las llanuras / y en los montes se añuda y se reduce, / grandeza es nueva siempre y grata, Argío, / tal, pero, es el autor que las produce. / ¡Oh Dios inmenso en todas sus criaturas.» Véase Medrano (2005: 112). 
divinamente de invisibles espíritus, como si sonasen allí un millón de caracolas marinas». Así, modulada entre lo tierno y lo terrible, brota la vena natural de las «rozze egloghe» que Sincero se propone repetir a los árboles y a unos pocos pastores, expresándolas «tan desnudas de ornamento, como bajo las deleitables sombras, al murmullo de las cristalinas fuentes, las oyó cantar a los pastores de Arcadia», porque son canciones que escuchan los dioses montaraces y las ninfas, «vencidos por su dulzura» ${ }^{16}$.

A todo ello se opone la modernidad de Utopía, que es situada por su autor en alguna indeterminada parte del Nuevo Mundo ${ }^{17}$ y cuyo humanismo se proclama más filosófico que poético y, no sin cariz polémico, más griego que latino ${ }^{18}$. En este país irreal, pero concebido en un momento en que las fronteras de lo real se están desplazando de modo asombroso, están prefigurados la planificación socialista de la producción y los ritmos de trabajo y de descanso dictados por el Estado y medidos por los relojes; la supresión de toda autarquía

16. He consultado Sannazaro, 2004. Las citas proceden del prólogo y de la prosa décima, con traducción mía.

17. Sobre lo que el diseño de la Utopía Thomas More debe a las noticias del Nuevo Mundo que circulaban en Europa se han dicho bastantes cosas, no pocas veces ajenas a todo método crítico. Los trabajos más serios tienden a mostrar que esas noticias aportaron aquí o allá un débil estímulo o un apoyo accesorio a una imaginación nutrida de lecturas filosóficas y cristianas. Véase Cave (1991) y Borges Morán (1995). Pero en cambio es difícil negar la poderosa influencia de la simple existencia de un Nuevo Mundo en cuanto implicaba la aparición en el ámbito real de algo nuevo e insospechado. Se ofrecía una página en blanco hecha mundo, una matriz de todo lo posible, donde podía diseńarse y ensayarse algo nunca visto antes, y esto no simplemente en palabras y conceptos sino en una imagen vívida y de metódica precisión.

18. Hythlodeus ha viajado con una pequeña biblioteca, y enseña a los utopianos unas pocas cosas útiles que ellos ignoran, como el arte de la imprenta. Queda maravillado del interés y de la facilidad que muestran para la adquisición de las letras y del pensamiento de los antiguos griegos, con quienes tienen una afinidad lingüística que indica la comunidad de la forma mental, y tal vez un secreto parentesco. Véase More (1995: 178-180): "Qui quuum a nobis accepissent de literis et disciplina Graecorum (nam in Latinis praeter historias ac poetas nibil erat quod videbantur magnopere probaturi) mirum quanto studio contenderunt ut eas liceret ipsis nostra interpretatione perdiscere». El viajero, que en este caso como en otros muchos, es claramente portavoz de Thomas More, muestra un desdén por las letras latinas de que hay otras huellas en la obra. Postergar a los romanos en favor de los griegos, es postura frecuente en el humanismo nórdico, en Erasmo y pensadores afines, y que no pocas veces va unida con el evangelismo, el pietismo, y la desconfianza hacia Italia. Eric Nelson, en varios trabajos, ha recalcado el alcance político de esta posición filohelénica, que supone un rechazo de los ideales del «humanismo cívico». Véase Nelson (2005). Según este estudioso, la visión romana de la república defiende los valores de libertad individual, justicia entendida como defensa de la propiedad mediante el desarrollo teórico y práctico de la ordenación jurídica, y vida activa del individuo que trata de conquistar el favor popular y sirve a la república en busca de la gloria para su patria pero también de su propia fama; por el contrario, la visión griega entiende la libertad no como independencia de la voluntad ajena sino como vida en armonía con la naturaleza, promueve los valores de justicia como distribución igualitaria de los bienes, autoridad sin límites de los mejores y más sabios, desdén de la opinión vulgar y de la fama, y vida contemplativa. Por ello, Utopía no se parece a la Roma republicana, como tampoco a la Roma imperial, y parece probable que quiera ser su directo contrario. 
familiar o local y el control riguroso de la relación entre población y territorio, que regula incluso el número de casas en cada ciudad y el número de adultos que viven bajo cada techo; los hospitales públicos en que se dispensa atento cuidado a los enfermos sin consideraciones de procedencia o fortuna; la educación universal y gratuita asegurada a hombres y mujeres. Estas y otras prácticas de Utopía, orientadas hacia el futuro, tendrían que esperar bastantes siglos antes de conocer conatos de realización.

Si Utopía se leyó como un juego de ingenio y por otra parte como un tratado político, Arcadia pudo leerse como un espejo en que afinar la experiencia de los deleites y dolores del amor como pasión, enfermizo pero sublime ${ }^{19}$. De hecho, los pastores, sus ocupaciones y su ambiente componen un fondo brumoso del que emergen con gran relieve detalles pintorescos o simbólicos aislados (no pocas veces citas de Ovidio, de Plinio y otros autores clásicos) y figuras o paisajes delineados con inaudita exquisitez. El paisaje arcádico, sin ciudades, sin mapas ni apenas caminos, es un horizonte sobre el cual se perfilan los procesos interiores, el dolorido sentir de los apasionados pastores, y en primer lugar de las figuras que representan al autor, Ergasto, Selvaggio y el narrador, Sincero. Por ello, tanto o más que en recuerdos de Virgilio, el libro abunda en ecos del Ovidio elegíaco, de Propercio y Tibulo y por encima de todos ellos, o sirviéndoles de excipiente, del Petrarca del Canzoniere ${ }^{20}$.

Todo lo contrario pues de la descripción metódica y analítica del autor inglés, concebida como una geografía-historia imaginaria (en una tradición que arranca de Heródoto), que empieza trazando un mapa físico y humano de Utopía para luego ocuparse de los espacios rurales y urbanos y de su administración, de las actividades de cada día, de la producción y distribución de los bienes, del control demográfico, de las exportaciones e importaciones, de las guerras y otras crisis históricas, para llegar finalmente a las relaciones con lo invisible y lo sagrado, la moral, la metafísica, la teología y la liturgia.

Arcadia deja profunda huella en el poeta más ilustre del Renacimiento castellano. Garcilaso de la Vega aprende de Sannazaro el tono elegíaco (a la vez patético, refinado e invisiblemente culto) de una voz situada en el escenario pastoril. Su égloga segunda, escrita poco después de 1530, reescribe el caso de amor vivido

19. Caracciolo (1995: 23): "L'amore che in Virgilio è desiderio, insania, passione, naturale appetito — non importa se etero od omosessuale — persuasore di morte, forza panica irresistibile da cui si è vinti senza averne felicità, nell'Arcadia di Sannazaro è una dimensione alienante, sfinimento, totale abbandono, che porta l'uomo afettato d'amore a dimenticare i saldi ritmi della vita bucolica, per lasciarsi naufragare in un'inerzia malinconica, in un totale distacco, un indifferenza, per cui ' $i$ fonti, le valli, i monti con tutte le selve' vengono riassorbiti in un paesaggio lontano, sfondo d'un solo sentimento, la malinconia d'amore."

20. Véase Saccone (1974) y las notas de las ediciones de Marino y Carlo Vecce. Véase también Gargano (2002) que atribuye a Sannazaro como su aporte propio lo que él llama la «liricización» de la bucólica. 
y narrado por Sincero junto con el de otro pastor cuya historia empieza como la suya, Carino ${ }^{21}$. El legado de las églogas en verso después de Garcilaso, quejas de pastores en una Arcadia trasladada a la geografía ibérica, y en un idioma romance al que se han incorporado hallazgos expresivos de Virgilio, Petrarca y Sannazaro, se complica en la novela pastoril española con elementos de vario origen. Desde la Diana de Montemayor a la Arcadia de Lope, estas novelas presentan, en prosa salpicada de versos, una gavilla de casos amorosos en que intervienen conflictos familiares, celos y confusiones de identidad, formando enredos de comedia y de novella amorosa. Con sus historias engastadas en una cornice de amable y discreta conversación, imbricadas y entrecruzadas, los libros de pastores, como los llamó Francisco López Estrada, construyen una mediación entre los modelos más populares de la narración larga del Renacimiento: el Decámeron, el Orlando furioso y la novela griega ${ }^{22}$. Por ello resultaron para los primeros lectores algo a la vez nuevo y conforme a sus expectativas, altamente atractivo y entretenido.

En este proceso la imaginación pastoril se va alejando de Sannazaro, y, si cabe, más todavía de su vertiente política y utópica. Sin embargo el recuerdo de la Arcadia retoña a finales del xvi y comienzos del xvir. En España hay al menos un libro que pertenece a la época de las Soledades y en el que se verifica la persistencia del modelo de Sannazaro: el Siglo de oro en las selvas de Erifile, libro de un poeta manchego afincado en México, Bernardo de Balbuena, que se publicó en Madrid en 1608, durante una estancia del autor en la corte. Como demostró Fucilla, este libro sigue el patrón de la Arcadia en concepción, estructura y lenguaje, tal vez con más fidelidad que cualquier otro libro de creación en español ${ }^{23}$. Pese a su cercanía al modelo, la corriente de inquietud política que aflora en la obra de Sannazaro no parece tener incidencia en la pastoral de Balbuena. El Siglo de oro en las selvas de Erifile es un brillante ejercicio de estilo, mediante la imitación de ilustres modelos italianos, latinos y españoles; por otro lado, de creer al mejor conocedor del conjunto de la obra de Balbuena, Rojas Garcidueñas ${ }^{24}$, incluye una autobiografía sentimental muy cautelosamente cifrada.

21. Vecce (2013: 25): «Il secondo ciclo può essere diviso in due parti, di cui la prima è appunto riservata al dittico Sannazaro-Carino e al racconto parallelo delle loro storie d'amore, che quasi si confondono, e sembrano una sola storia».

22. Francisco López Estrada (1952: 161-169).

23. Fucilla (1947: 118): "Balbuena, as we have seen, made use of a fair number of sources for his Siglo de Oro: the "Arcadia", two Sannazaro poems, the "Eclogues", "Georgics" and "Aeneid" of Virgil, Petrarch, Garcilaso, Boscán, Montalvo and perhaps Ariosto, Lomas Cantoral and Gil Polo. Excepting Virgil and Sannazaro all of these authors provide him with occasional ornamental details to beautify his work; Virgil supplies important matter in the second eclogue, but otherwise imitations from him likewise have a decorative function throughout the rest of the pastoral. With Sannazaro is different. [...] It does, indeed, appear that Balbuena had this work ["Arcadia"] at his elbow during the whole process of its composition."

24. Rojas Garcidueñas (1958).

Studia Aurea, 8, 2014 


\section{¿Soledades arcádicas o utópicas?}

Los ecos de la tradición pastoril considerada en toda su amplitud y en concreto los de la Arcadia de Sannazaro, se combinan de forma explosiva con elementos de muy distinto origen en las Soledades de Góngora (1613-1617) ${ }^{25}$, tal vez la obra poética del siglo XVII que causó mayor sensación y tuvo más honda influencia en la poesía posterior. Sus dos partes, Soledad primera y Soledad segunda, en conjunto unos dos mil versos, se unen por un hilo narrativo que se rompe antes de lo que debió de preverse como final del segundo poema. Puede afirmarse con certeza que la historia transcurre en un territorio que bordea el litoral atlántico, con una parte de sierra, y otra parte de arenales y marismas, en una época posterior a la era de los grandes descubrimientos. El texto no incluye topónimos o nombres propios de persona que permitan identificar su referente geográfico. Pedro Espinosa, que fue amigo del poeta y capellán y secretario del VIII duque de Medina Sidonia, reconoció a su señor, por entonces conde de Niebla, en la persona de un príncipe a caballo descrito en unos versos de la Soledad segunda ${ }^{26}$. Por ello, y por ciertas imprecisas coincidencias topográficas, hay quien ha creído que el poema, especialmente en su segunda parte, está ambientado entre Huelva y Cádiz, entre los feudos de Medina Sidonia y los de los marqueses de Ayamonte, aristócratas a quienes Góngora dedicó bastantes poesías ${ }^{27}$.

Aun admitiendo que esta referencia se dé efectivamente en el poema, cosa probable pero no demostrada, no hay que olvidar que el poeta quiso que fuera incierta, ambigua y en el mejor de los casos, confidencial. La región recorrida en las Soledades no es declaradamente Huelva, Cádiz ni ninguno de los dominios de los grandes de España de quien era amigo o «cliente», en el sentido romano, Góngora: dominios cercanos a esa encrucijada, vital para el imperio hispánico, entre las rutas náuticas del Mediterráneo y las de ambos océanos.

El carácter ideal de la región representada, como sucede en el gran arte idealista del Renacimiento, en Rafael, Miguel Ángel, Tiziano y, ya en el XviI, en Rubens o en Poussin, no contradice la llamada imitación de la naturaleza: entendamos el carácter concreto, objetivo y plástico, además de racional y coherente, de la representación. Su relación con los señoríos de Medina Sidonia o Niebla es comparable a la que tiene con el Andrea Doria histórico el retrato por Agnolo Bronzino del gran almirante como Neptuno, casi desnudo, con un tridente en la mano y con una cabeza lo bastante griega y noble para ser la de un dios antiguo ${ }^{28}$, pero

25. Véase Cacho Casal (2007): un excelente trabajo y único de momento, que sepamos, dedicado a la presencia de la Arcadia de Sannazaro en las Soledades de Góngora.

26. Elogio al retrato del excelentísimo señor don Manuel Alonso de Guzmán, duque de Medina Sidonia, Málaga, 1625. Espinosa (1991: 265-266).

27. Véase Ponce Cárdenas (2008 y 2009).

28. Ritratto di Andrea Doria come Nettuno, Milán, Pinacoteca de Brera. Otra versión del cuadro, que ha sido atribuido a Sebastiano del Piombo o al mismo Bronzino, se encuentra en la Galería Doria Pamphili de Roma. 
observando puntillosamente cierto parecido con el retratado y las marcas de una vejez paradójicamente floreciente. Del mismo modo, en caso de que en efecto las Soledades traten de la citada zona, esta aparece trasladada a un lugar que es un no-lugar, una utopía. Por lo demás en el poema (o en las escasísimas declaraciones de Góngora que han llegado hasta nosotros) no hay nada equivalente a la cartela con el rótulo «Andrea Doria» que en el cuadro de Bronzino identifica al retratado.

Robert Jammes resume con pericia minuciosa el argumento del poema en su magistral edición ${ }^{29}$, por lo que nos limitaremos a un sumarísimo y descarnado recordatorio ${ }^{30}$. Un joven naúfrago que al abrirse el relato vemos aferrado a una «breve tabla» es «vomitado» por el Océano en una costa desconocida. En lenguaje cultamente cifrado, pero inequívoco, se nos dice que es noble, bellísimo, cumplido ejemplo de cortesanos y de enamorados. En ningún momento el poeta da nombre propio a esta "principal figura" ${ }^{31}$; muy a menudo lo designa como el peregrino o nuestro peregrino, de modo que esta perífrasis, supliendo la carencia de nombre propio, denomina por antonomasia al protagonista, también designado como el joven, el náufrago, el mancebo, el forastero, el huésped o el extranjero. El relato sigue los pasos de esta figura, que, a falta de toda dirección determinada por un proyecto o empresa, pueden ser calificados de errantes, como anuncia, desde su famosa apertura, la dedicatoria al duque de Béjar:

Pasos de un peregrino son errante cuantos me dictó versos dulce Musa [...]

Después de salir del mar y secar sus ropas, el naúfrago escala unas rocas y se encuentra frente a un "vasto golfo de sombras» en el que discierne una lejana luz hacia la que endereza sus pasos. La estrella que lo guía resulta ser, vista de cerca, un enorme fuego encendido por unos cabreros en donde arde una encina entera. Desde ese momento nuestro personaje salvado de las aguas goza de la hospitalidad de los pobladores de esta desconocida tierra, pasando de un grupo a otro durante cuatro días en que lo vamos siguiendo paso a paso: durmiendo una noche en la majada de los cabreros hallados en torno al fuego; caminando por sierra y campo en compañía de un grupo de serranos, hombres y mujeres; asistiendo como convidado de honor a unas bodas de labradores; visitando un islote cercano a la costa donde lo agasajan un pescador y sus hijas; paseando en barca con dos jóvenes pescadores que lo llevan cerca de un castillo, de donde ven salir a una tropa de cazadores cetreros. La barca sigue a los jinetes, con sus perros y halcones, por una zona de marismas y se inmoviliza en una ribera de cañas y barro, donde queda bruscamente truncado el discurrir de un poema que no presenta sin embargo ninguna señal de improvisación o descuido.

29. Jammes (1994: 22-34).

30. Jammes (1994: 544-6: Nota a Soledad segunda, verso 811).

31. La expresión es de Juan de Jáuregui en el Antídoto contra la pestilente poesía de las Soledades. 
Numerosos motivos de las Soledades evocan la Arcadia de Sannazaro, y dialogan con la tradición que esta obra funda tanto retrospectiva como prospectivamente. En ambas obras, la narración carente de tensión dramática va siguiendo con regularidad la sucesión de los días y las noches: las gentes de campo son descritas en unas actividades en que el trabajo no se ha separado francamente del ocio, ni el esfuerzo de la fiesta. Pastoreo, horticultura, pesca, caza, lucha, salto y carrera, cantos y danzas, banquetes y amores se integran en un continuum de prácticas colectivas que vincula la necesidad de procurarse el sustento con el apetito de goces y regocijos. Estas actividades siempre son acompañadas o enmarcadas por charlas, discursos, música instrumental o cantada.

Thomas More tiene una concepción burguesa o moderna del tiempo con horas dedicadas al trabajo y otras al ocio (ocio de humanista empleado en actividades liberales, no abandonado a la inacción y holgazanería). Este dispositivo separa estrictamente ambos tiempos como coacción y libertad, labor forzada y ejercicio feliz de las potencias. La gran innovación de su libro, y su diferencia capital con respecto a su modelo más cercano, la República de Platón ${ }^{32}$, consiste en defender que es justo y factible que cuantos pueblan la república compartan una y otra faceta de la existencia. O más bien, la gran mayoría, compuesta por una nutrida clase media limitada por dos minorías inferior y superior, porque hay en Utopía algunos esclavos (presos de derecho común o cautivos de guerra) y unos pocos privilegiados exentos de trabajo manual. No labran la tierra ni trabajan en talleres los miembros de una intelligentsia muy selecta y muy vigilada (aunque no se sepa muy bien por quién) de individuos que tienen vocación y talento para el estudio; en esta clase se eligen los magistrados, los sacerdotes y el mismo princeps $^{33}$. Sin embargo nadie pertenece a estas clases de nacimiento ni está abocado a quedarse en ellas de por vida; el letrado poco productivo debe regresar a la categoría de los trabajadores manuales, el trabajador puede mostrar dotes y gusto por el estudio y volverse sabio de profesión y el esclavo puede hacer méritos para integrarse en la ciudadanía.

En cambio Sannazaro, como los antiguos, imagina en su Arcadia unas actividades compartidas por una comunidad de "pastores» que conjugan labor agrícola, ganadera y artesana y juegos y festejos deportivos, musicales y poéticos, presentados como dos caras de la misma moneda, y que pueden desarrollarse casi a un

32. Steintrager (1969). La república ideal descrita por Platón está estrictamente dividida en clases de distinta dignidad y en ella el trabajo manual no es cosa en que tengan que participar los mejores ciudadanos. De hecho, Thomas I. White ha demostrado que en estos aspectos, y en ciertas ideas importantes del diseño de Utopía, como por ejemplo la auto-suficiencia del Estado ideal, Thomas More está más bien en deuda con la Política de Aristóteles. Véase White (1976).

33. Los exégetas y traductores de More no se ponen de acuerdo sobre el estatuto de este princeps, que podría ser un monarca electivo, o una especie de gobernador o presidente vitalicio. El texto es muy preciso en otros aspectos, aunque a veces esta precisión lleve a contradicciones insalvables, como hace ver Marin (1973). Pero en este punto se muestra de una notable vaguedad, probablemente voluntaria. Véase Baker (1993). More (1995: 144-145). 
propio tiempo. Con lo que se niega implícitamente que lo que hacen los rústicos sea un trabajo forzado, rudo, penoso y necesariamente servil. Esta visión poética de una vida rural que no disocia placer y trabajo vuelve superfluos el estricto horario laboral y las disposiciones coercitivas imaginados por More para impedir que sus utopianos, en una sociedad sin dinero y sin propiedad privada, intenten defraudar a la colectividad de las horas de trabajo que le deben. Así el ciudadano de Utopía no puede ausentarse de los alrededores de su ciudad sin permiso de las autoridades; si va de excursión al campo, debe participar en el trabajo de las granjas cercanas para que le den de comer; si viaja más de un día a otras ciudades, está obligado a ejercer allí su oficio en alguno de los talleres locales ${ }^{34}$. Nada de esto tendría sentido en $\mathrm{Ar}$ cadia, donde no hay espacios separados para el trabajo, como tampoco para el ocio letrado, ni tendría sentido en el país soñado por Góngora que por ello es un avatar de la intemporal "arcadia», alejado del régimen utópico, o más bien utopiano.

El parentesco de las Soledades con la obra de Sannazaro, patente en esta fusión del trabajo y del ocio en las sociedades imaginarias descritas, se verifica en algunos incidentes narrados. El episodio de los «juegos» o competiciones deportivas, que concluyen las fiestas de boda de la Soledad primera, y que responde a un lugar común de la épica y no de la bucólica, ya figuraba en la Arcadia del napolitano, en la prosa XI que narra juegos fúnebres en honor a Massilia ${ }^{35}$. Sannazaro se inspiraba en la Eneida de Virgilio y en la Tebaida de Estacio ${ }^{36}$. Góngora compone tres cuadros breves (la lucha, el salto, la carrera) con la densidad que lo caracteriza, engastando en ellos teselas donde la imitación de Sannazaro deja ver como por transparencia la lectura directa de la Tebaida.

En la Arcadia de Sannazaro, que prolonga la égloga décima de Virgilio, única ambientada en esta región griega, se marcaba un vívido contraste entre los alegres rituales y ejercicios colectivos y la soledad desesperada de individuos que cultivan el amor pasional y la melancolía. Las églogas y las prosas de la segunda mitad de la obra cuentan historias de enfermedad amorosa llevada al paroxismo: las de Sincero en la égloga VII, Carino en la prosa VIII, Clonico, que la pasión ha enfurecido hasta la bestialidad, en la égloga VIII. Pero ya en la primera prosa, la figura taciturna, inerte y prostrada del que no se deja incluir en la feliz comunidad aparece

34. More (1995: 144-145).

35. Vecce (2014: 34): "La densità intertestuale dell'intero episodio dei giochi pastorali (un mosaico di testi da Virgilio, Omero e Stazio) è un'altra dimostrazione dell'alto livello raggiunto dal classicismo di Sannazaro, di superamento dei confini del genere bucolico con la rimodulazione di testi epici e con scarti anche verso il registro comico-rusticale (altrimenti raro nell' "Arcadia"). Possibile un'allegoria politica: la competizione sportiva è proiezione pastorale delle lotte sociali e politiche contemporanee, che però la sapiente guida di Ergasto riesce sempre a ricondurre alla pacificazione e all'armonia.»

36. Cacho Casal (2007) analiza finamente las relaciones entre las competiciones deportivas aldeanas en las «pastoriles bodas» (Soledad primera, vv. 958-1064), los juegos de la prosa IX de Sannazaro en honor de Masilia, y los juegos de Thebaida, VI. Sannazaro imita a Estacio, y, siguiendo su ejemplo, Góngora imita al mismo poeta latino de modo muy selectivo y denso, recordando aquí o allá la transposición de Sannazaro. 
como elemento clave del dinamismo narrativo del libro. En las alturas del monte Partenio, en un lugar marcado por un círculo de «doce o quince árboles, de tan extraña y excesiva belleza» que parece que naturaleza ha extremado en ellos su arte, donde los pastores se entretienen con juegos y competiciones de arco, salto y lucha, haciendo "maravillosa fiesta», uno de ellos, el único que interesa al narrador como individuo, se abstrae por completo de esos placeres: "Ergasto solo, senza alcuna cosa dire o fare, appié di un albero, dimenticato di se e désuoi greggi, giaceva, non altrimente che se una pietra o un tronco stato fusse». Se trata de un dispositivo narrativo-retórico recurrente en la égloga tal como Sannazaro la concibe, y por él la subjetividad se inscribe como enfermedad, dolor, abandono de sí, negligencia de los propios negocios, sombra o taller secreto en que se labra y se afina el canto, y en definitiva como algo que desentona en el conjunto regular y armonioso de los trabajos y los días en que se cimenta la sociedad. La antítesis entre individuo doliente y feliz quehacer colectivo, definitoria del mundo arcádico en la décima égloga de Virgilio, también figura en las églogas latinas del napolitano, ambientadas entre pescadores, y cuyo recuerdo actúa en la Soledad segunda:

\author{
Dumque alii notosque sinus piscosaque circum \\ aequora collustrant flammis aut linea longe \\ retia captivosque trahunt ad litora pisces \\ ipse per obscuram meditatur carmina noctem. (Ecl. Pisc., II, 4-7) ${ }^{37}$
}

'Mientras los demás alumbran con las llamas de sus linternas las calas que bien conocen y los mares ricos de pescado de aquellos contornos, o arrastran hacia la ribera los peces que han cautivado a lo lejos en sus redes de lino, él medita sus canciones en la sombría noche.' (traducción propia)

El contraste que se verifica entre la tristeza del peregrino de Góngora y la alegría que acompaña el quehacer de pastores, labriegos y pescadores, sólo se tematiza en contadas ocasiones ${ }^{38}$. La oposición entre la sociedad feliz y el individuo ensimismado y doliente no deja sin embargo de afirmarse en las Soledades, de modo menos patético pero también más nítido y más estable que en el escritor napolitano, puesto que un solo individuo es marcado como distinto frente a una colectividad de semejantes. De un lado están los pobladores del orbe rústico que se dividen en varios grupos — cabreros, labriegos de la sierra y del llano, pescadores y cazadores—; del otro, el peregrino, que no participa activamente en nada y mantiene en todo mo-

37. Sannazaro 2009, 112,

38. I, 507-512: La triste historia del peregrino que iba a ser contada no llega a empezarse porque se pone en marcha la alegre comitiva de los villanos que prosiguen su viaje hacia la aldea de las bodas; I, 732-754: la visión de la bella novia labradora reanima en el peregrino el recuerdo doloroso de su dama; II, 102-172: mientras los pescadores llevan a cabo las faenas de una pesca milagrosa por su abundancia, el peregrino profiere su «métrico llanto», una canción desesperada en que aspira a la muerte como único descanso; II, 652-675: el narrador compara la felicidad amorosa de los pescadores y el infortunio del peregrino. 
mento su diferencia. Él es noble y los demás son villanos (exceptuando al príncipe a caballo ya mencionado que se entrevé hacia el final de la Soledad segunda); él es distinguido, tiene una "calidad» de que dan "señas» sus "paños»" ${ }^{39}$, es decir, significada en el traje de corte, y los demás son iguales entre sí; él es errante y los demás son sedentarios y están enraizados sólidamente en su mundo; él desea algo que parece perdido para siempre y ese deseo lo desgarra; ellos desean lo que tienen a mano, lo obtienen y son felices. De modo que el acento elegíaco de la representación, que en Sannazaro y en otras Arcadias renacentistas permea la mayor parte del texto y toca a muchos personajes, está aquí circunscrito y acotado en la figura del peregrino, del forastero, huésped, extranjero. Lo que se nos cuenta es pues la mirada de un extraño desplazándose sobre la pantalla de un mundo feliz en cuya felicidad no participa. Sin embargo esa mirada no afecta, salvo muy esporádicamente, la representación de la felicidad. El peregrino, pese a la índole magnánima de sus sentimientos, es empequeñecido, apenas se le deja expresarse (fuera de la canción al borde de la barca y destinada al mar y al viento que se pone en sus labios ya muy avanzada la narración ${ }^{40}$ ). La alteridad marcada entre Hythlodeus y Utopía, siendo el primero un puro observador de cuyas vivencias en la isla apenas sabemos nada y que no parece integrado en su universo, es similar a la del peregrino de Góngora, simple «mirón», como escribía Jáuregui, con respecto a la región que lo hospeda. Nunca llega a interferir su estado de ánimo en la representación del mundo rústico, constantemente eufórica.

Ciertamente hay quien ha visto a este respecto una diferencia entre las dos Soledades, porque la primera presentaría un mundo apacible y sin violencia; la segunda reintroduciría esta violencia en escenas sanguinarias, la caza de animales marinos por las hijas del viejo pescador (II, 418-511) y sobre todo los incidentes de la cetrería con que se cierra o se interrumpe el relato (II, 831-979). Las escenas en que muere un doral en las garras de un baharí y en que una cuerva es víctima del «gémino rigor» de un jerifalte y de un sacre señalarían la ruina de la idílica paz agreste. Creemos por nuestra parte que, para los lectores de tiempos de Góngora, tan agreste y tan placentera era la caza cetrera del segundo poema como los epitalamios, carreras, cantos y danzas del primero, donde se incluye también por cierto una excitada cacería de lobo. La idea de la caza como un ejercicio cruel era por lo general ajena a una época en que la esperanza de erradicar la violencia sufrida por los seres humanos - manifiesta en el bandolerismo, la inseguridad urbana, las constantes guerras, los castigos físicos- parecía suficientemente remota para que uno no se complicara la vida compadeciendo también el sufrimiento animal. La cetrería es un gran espectáculo y, si se presenta con los colores de lo trágico ${ }^{41}$, sólo

39. I, 528-9.

40. II, 112-171.

41. Véase una interesante lectura reciente del episodio de la cetrería como tragedia sin patetismo en Elvira (2014). 
puede ser en modo menor y a manera lúdica. Su contemplación es compatible con el epicureísmo de un Lucrecio que encuentra un suave refrigerio en mirar los naufragios desde la orilla.

Es cierto sin embargo que Thomas More había excluido la caza de las actividades de sus utopianos, alegando que la costumbre de matar a animales indefensos, además de fundarse en un placer artificial, un dolor convertido en deleite por la corrupción que engendran hábitos contra natura, prueba un temperamento cruel y acaba embotando la compasión por el sufrimiento ajeno:

Aut quae suavitas esse potest ac non fastidium potius in audiendo latratu atque ululatu canum? Aut qui maior voluptatis sensus est cum leporem canis insequitur quam quum canis canem? Nempe idem utrobique agitur, accurritur enim, si te cursus oblectet. At si te caedis spes, laniatus exspectatio sub oculis peragendi retinet, misericordiam potius movere debet, spectare lepusculum a cane, imbecillum a validiore, fugacem ac timidum a feroce, innoxium denique a crudeli discerptum. Itaque Utopienses totum hoc venandi exercitium, ut rem liberis indignam, in lanios (quam artem per servos obire eos supra diximus) reiecerunt. Infimam enim eius partem esse venationem statuunt, reliquas eius partes et utiliores et honestiores ut quae et multo magis conferant et animalia necessitatis dumtaxat gratia perimant, quum venator ab miseri animalculi caede ac laniatu nibil nisi voluptatem petat. Quam spectandae necis libidinim in ipsis etiam bestiis aut ab animi crudelis affectu censent exorire, aut in crudelitatem denique assiduo tam efferae voluptatis usu defluere. ${ }^{42}$

La traducción, aunque en este pasaje bastante descuidada e inexacta, de Jerónimo de Medinilla — corregidor de Córdoba pocos años después de la muerte de Góngora-, nos parece digna de conocerse:

¿No puede ser antes mayor fastidio el oír ladrar los perros? O qué mayor deleite el ver un galgo seguir la liebre, que un perro ir en el alcance de otro? Porque verdaderamente se ve la velocidad de correr de aqueste y de aquel modo. Si deleita el ver despedazar y matar aquel animalejo, debería antes mover a piedad la liebrecilla flaca, fugitiva, tímida, inocente ser despedazada del galgo feroz y cruel. Así los de Utopía han contradicho del todo el ejercicio de la caza, como arte conveniente a carniceros cuyo uso han cometido a sus esclavos, juzgando que el cazar sea de aquélla la más infima parte; y la otra tienen por mas útil y honesta, cuando se matan los animales por la necesidad de la vida humana, y el cazador solamente toma gusto con la muerte del mísero animalejo, y este deseo piensan que nace de un ánimo dispuesto a la crueldad. ${ }^{43}$

La postura definida en estas líneas, en armonía con un pacifismo de tipo erasmiano, de signo pietista y evangélico, prolonga en la cultura cristiana opiniones no desconocidas en el mundo clásico, y que cobran un sesgo radical en la doctrina de Pitágoras, quien, según ciertos testimonios, proscribía los sacrificios

42. More (1995: 170).

43. Medinilla y Porres (1637: fol. 23r.). 
sangrientos, base de la religión ciudadana; lo que contribuyó, según Detienne, a acarrear el descrédito y la marginación de los pitagóricos ${ }^{44}$. De modo comparable, la aversión de los utopianos por la caza está en abierta pugna no sólo con los gustos y los hábitos, si no con la razón de ser de la nobleza feudal y de la aristocracia cortesana de Europa, cuyos privilegios se justifican con la dedicación preferente a la guerra. Por ello semejante postura, de la que no conocemos testimonios entre los contemporáneos españoles de Góngora, en caso de darse, tenía que verse por fuerza como sospechosa, o al menos como extravagante y risible. Es cierto que la violencia de la caza puede ser un conato de ruptura del sueño arcádico, como sucedía ya muy posiblemente con la caza de pájaros, que practica el pastor Carino con su amada en la prosa VIII de la Arcadia, en un pasaje fielmente adaptado por Garcilaso $^{45}$. El relato insiste en exquisita fruición que la pareja de adolescentes hallan en el espectáculo del sufrimiento causado a los animales. Este goce sádico resulta más inquietante por hallarse unido a la delicada belleza juvenil, al casto amor inexpresado y a la perfecta buena conciencia. La impresión de crueldad se deriva no sólo del sufrimiento gratuito y prolongado infligido a las aves sino del sarcasmo y la humillación supremos de forzar a las víctimas a ser cómplices de sus verdugos. Los pájaros, inofensivos, manipulados por los astutos y despiadados jóvenes, llevan involuntariamente a sus congéneres a una muerte atroz, o a perecer en masa, hasta el punto de causar hastío en los mismos cazadores ${ }^{46}$. Hasta cierto punto algo similar se produce en el episodio cetrero de las Soledades, puesto que este tipo de caza implica que los pájaros sean utilizados para torturar y matar a los mismos pájaros. No deja de ser muy distinto puesto que la "generosa industria» de los halconeros canaliza un instinto de predadores que ya existe en las aves cetreras y que ellas ejercen también estando en libertad, mientras que el

44. Detienne (1970: 143): "Manger de la viande, c'est commettre un meurtre. Or, l'assassinat dont le maître veut détourner ses fidèles ce n'est pas verser le sang d'un citoyen ou d'un parent, c'est porter la main sur des animaux qui ont en commun avec nous le droit de vivre et qui possèdent une âme. Manger de la viande, c'est commettre un meurtre (phoneuein). Et l'équivalence entre les deux termes est si rigoureuse que Pythagore, raconte Eudoxe de Cnide, refusait d'être en contact avec les cuisiniers et les chasseurs, qu'il considérait comme des criminels (phoneuontes)."

45. Sannazaro (2014: 186): "Nella storia dell'amore infelice di Carino si registra una differenza fondamentale rispetto a quella del suo doppio Sincero: la lunga digressione dell'uccellagione praticata dal pastore e dalla sua amata. Derivato in parte dai Ruralia commoda del Crescenzi (10, 17-28) e in parte della caccia di Ameto e Lia nella Commedia delle ninfe fiorentine di Boccaccio, il brano acquista il carattere inconsueto e perfino sadico di vero 'teatro della crudeltä: i due fanciulli si divertono nelleideare le trappole e nel vedere soffrire gli animali. Ancora una volta, l'Arcadia rivela una dimensione profonda di violenza e di morte, non giustificata dalla possibile allegoria (negli uccelli che perdono la loro libertà, invischiati, torturati e uccisi, si rispecchiano gli stessi pastori-cacciatori, vittime della malattia d'amore). Gli uccelli ("umanizzati» nella rappresentazione dei loro sentimenti e delle loro sofferenze) mettono a nudo il fondo oscuro della follia umana..."

46. Sobre esta lectura del episodio véase Fenzi (2009: 86-88), que remite en sus notas a la tradición que reprueba el consumo de carne y la crueldad hacia los animales, desde Plutarco, que asume en este punto la postura de los pitagóricos, hasta Arnaldo de Vilanova. 
daño que causan unos pájaros a otros en el episodio de Sannazaro es ajeno a su naturaleza e impuesto por los cazadores. Por lo demás hay pruebas textuales más que suficientes de que Góngora narra el espectáculo de los "pendientes agradables casos» - los lances de la caza en las alturas del cielo, y las caídas de los pájaros que pierden la vida en las garras de los halcones - como algo superiormente deleitable. Así lo leyeron sus contemporáneos, y ninguno de los comentaristas deja entrever el sentimiento de algo triste o sombrío en este pasaje. El efecto que de él se desprendía era el de lo maravilloso, lo mirabile, en tanto la "generosa industria» de los cazadores ponía en escena las maravillas naturales del vuelo de los halcones, de la rapidez fulminante, de la ferocidad majestuosa. Un fragmento del sermón pronunciado en las fiestas de Lerma de 1617 por el amigo de Góngora, fray Hortensio Félix Paravicino, es la reconocible transposición del relato cetrero de la Soledad segunda ${ }^{47}$. Esta variación oratoria del episodio poético, valioso testimonio de una recepción inmediata, confirma que los incidentes de la persecución y alcance de las aves hacián de este tipo de caza un placer exquisito y propio de reyes. Mágicamente recreados por el verbo incandescente del poeta, comunicaban al lector este «gusto real» cuyo goce directo excedía sus recursos y que, aun en caso de tener algo de atroz y sanguinario, lo perdía bajo esta forma sublimada e inmaterial. Aunque fuera monje, teólogo, y de hábitos ascéticos, este lector, debía, si era hombre de gusto, ceder a los encantos de unos combates tan bellos y de unas muertes tan hermosamente contadas ${ }^{48}$. En definitiva el texto no fuerza a plantear el problema moral de la caza. En el caso de que éste se dé, queda confinado en el margen del mundo imaginado por Góngora, y funciona a lo sumo como presagio de un malestar o indicio de una contradicción latente, que tal vez, sólo tal vez, tenga algo que ver con esa especie de muro invisible en que viene a estrellarse el poema y que impide su continuación.

Pese a no excluir todo tipo de violencia, puede afirmarse sin vacilar que el poema representa un mundo feliz en un entorno rústico y marinero no situado geográficamente. La localización indeterminada y los individuos sin nombre propio ni historia que pueblan este mundo lo convierten en idea o entelequia, pese a la multitud de detalles concretos. El que sea plenamente feliz, de manera permanente y no accidental, constitutiva y no anecdótica, le confiere un carácter utópico.

Esa felicidad se prueba en el trato y costumbres de esa sociedad. Porque es feliz, ejerce con el peregrino una hospitalidad digna de la Edad de Oro. Los cabreros lo acogen con "pecho igual de aquel candor primero/que, en las selvas contento,/ tienda el fresno le dio, el roble alimento» (I, 140-2). El «político serrano, de canas grave», le convida con fina cortesía a la boda, y la piedad que en él despiertan las manchas en su traje cortesano, dejadas por el agua de mar, ya lo «hospeda en su

47. Blanco (2012: 60-62).

48. Este fue de hecho uno de los pasajes más imitados, incluso en el contexto de alguna epopeya sacra. Véase Ponce Cárdenas (2013b). 
alma», antes de convidarlo a su aldea (I, 529). La tropa de invitados a la boda que se embarcan para volver a sus lugares del otro lado de la ría se despide del forastero «usando al entrar, todos, cuantos les enseñó corteses modos/ de la lengua del agua ruda escuela» (II, 56-58). Los dos pescadores en cuyo pequeño bajel se introduce le piden licencia para echar sus redes (II, 73). El viejo pescador que vive en la isla "acogió al huésped con urbano estilo» (II, 216). En suma, nada de rudo o de «fiero» tiene el trato de estos rústicos, tanto entre sí, como con el extranjero; de modo constante y unánime, es a la vez generoso, sencillo y deferente. Ya entre los simples y callados cabreros la comida se presenta como un maravilloso bodegón, las pieles blandas que ofrecen al huésped para dormir le procuran un sueño «más regalado» que el que goza el príncipe entre «holandas, púrpura tiria y milanés brocado» (I , 165-6). La exquisitez de las cosas que poseen y liberalmente ofrecen los villanos, las sensaciones placenteras que procura la estancia entre ellos, se expresan con incansable insistencia en el estilo más culto que hasta entonces se diera en la lengua espańola. La frugalidad de sus costumbres no tiene nada de escasa ni de sórdida, todo se da entre ellos con torrenciales abundancia y liberalidad. La belleza reina por doquier: en las mujeres, en el paisaje, en las acciones y gestos, en los discursos, en los rituales y en la música. La alegría es constante; la disposición benévola, inagotable. Todo es honesto pero a la vez «lascivo» y nadie ni nada presenta un semblante severo, un ceño autoritario. Abundan en el texto referencias a Diónisos y a sus ritos, a Venus y sus juegos. No hay desórdenes pero tampoco órdenes, la disciplina es espontánea, sin «rumor», sin que haya nada estentóreo ni ostentoso. Así convida a comer el padre de la novia a todos cuantos se han reunido en la aldea:

Llegaron todos, pues, y con gallarda

civil magnificencia, el suegro anciano cuantos la sierra dio, cuantos dio el llano, labradores convida, a la prolija rústica comida que sin rumor previno en mesas grandes. (I, 852-6)

He aquí cómo se desarrolla la comida en casa del pescador:

Nieve hilada, y por sus manos bellas caseramente a telas reducida manteles blancos fueron.

Sentados, pues, sin ceremonias, ellas en torneado fresno la comida con silencio sirvieron.

Rompida el agua en las menudas piedras cristalina sonante era tïorba y las confusamente acordes aves entre las verdes roscas de las hiedras, muchas eran, y muchas veces nueve aladas musas que, de pluma leve 
engañada su culta lira corva, metros inciertos sí, pero süaves, en idiomas cantan diferentes, mientras, cenando en pórfidos lucientes, lisonjean apenas al Júpiter marino tres sirenas. (II, 343-360)

Resalta en estos pasajes el modo liso y suave en que las cosas se hacen, el que no haya ruido sino un incesante acompańamiento musical, como si el estar con los demás fuera intervenir en una coreografía perpetua o en una vida cantada y bailada. Incluso el bullicio y el alboroto son armoniosos, nunca suponen molestia o estridencia. La aparición de grupos y de individuos es regularmente anunciada por la música. Al comienzo de la Soledad segunda, el gentío compuesto de labriegos que vuelve a su casa del otro lado de la ría después de haber asistido a las bodas (y que el poeta designa con la gráfica y extraña expresión el villanaje ultramarino), ve acercarse una barquilla en que suena la dulce voz doliente de un pescador enamorado. Para no interrumpir la tierna canción, la «turba» hace «señas mudas» a otro barco de mayor capacidad que ha aparecido de repente («la que de un ancón segunda haya salió improvisa») y al que quisiera dar voces, puesto que se propone embarcarse en él para atravesar la ría. Es un ejemplo entre otros de la delicada manera que tiene el pueblo de este país imaginario de respetar la armonía sin sufrir ninguna coacción:

Señas mudas la dulce voz doliente permitió solamente,

a la turba, que dar quisiera voces

a la que de un ancón segunda haya

(cristal pisando azul con pies veloces),

salió improvisa, de una y otra playa

vínculo desatado, instable puente. (II, 42-48)

Los personajes revestidos de autoridad, únicamente tres ancianos — $\mathrm{el}$ "político serrano", antiguo mercader padre de un hijo muerto en el mar y "cabo" o capitán de las serranas que viajan para ir a la boda ("Cabo me han hecho, hijo/ deste hermoso tercio de serranas» I, 516-17), el padre de la novia aldeana y el viejo pescador que hospeda al peregrino en la Soledad segunda-, son dispensadores de bienes: ofrecen y presiden convites, ponen su experiencia, saber y elocuencia al servicio de los demás. Apenas ordenan nada, no prohíben ni reprimen nada, y cuando pretenden hacerlo, no son escuchados por los impacientes, vitales, heroicos jóvenes. Así, una de las pescadoras se engolfa sola para combatir a focas y monstruos marinos, sorda a las voces del padre que teme algún mal encuentro (II, 453-465). Así, el viejo que acompaña a las serranas, comparado con un Sileno conductor de bacantes, no impide que toquen tejoletas, bailen lascivamente o enjuaguen con las rosas de su cara el sudor de las frentes de los novios (I, 569-572). Tampoco impide el prudente temor del viejo los peligrosos fuegos de artificio ni el frenesí del baile aldeano: 
Los fuegos pues el joven solemniza, mientras el viejo tanta acusa tea al de las bodas dios, no alguna sea de nocturno Faetón carroza ardiente y miserablemente campo amanezca estéril de ceniza la que anocheció aldea. (I, 652-658)

El optimismo reinante es pues el de la antigua y moderna comedia, donde los jóvenes y los enamorados siempre tienen las de ganar. La felicidad amorosa se da por descontada entre estas gentes, puesto que Cupido, Venus e Himeneo, lo mismo que Baco, Ceres o Palas, se les muestran favorables. El trabajo y el esfuerzo se consideran bajo el ángulo de lo heroico, o de lo deportivo, de la exhibición de fuerzas y de la noble competición. Los labradores portadores de regalos que van desfilando como en un friso se reducen a los robustos hombros que llevan las prodigiosas cargas de gallinas o de conejuelos como llevarían trofeos, o como Alcides llevaría su clava. Estos rústicos son atletas griegos y se nos pintan como «valientes desnudos labradores» (I, 962) en «olímpica palestra», «soberbios montañeses», o «musculosos jóvenes desnudos» (II, 580). También tienen algo de paladines de Ariosto, que gustan con cierta cándida fatuidad de exhibir su valor y esfuerzo. Al ir caminando hacia la aldea, todos se arrogan, como caballeros caminando hacia un torneo, los "consignados premios", "ya al formidable salto, ya a la ardiente/ lucha, ya a la carrera polvorosa» (I, 565-6). Hasta «el menos ágil» ya desafía a "cuantos comarcanos convoca el caso" y promete "consagrar los palios a su esposa».

Nos tentaría proyectar en el texto una extraña anticipación del realismo socialista o de la exaltación soviética de los trabajadores, si no fuera por el cariz arcádico de la representación. La celebración se opera con la mediación de una reescritura de Catulo, Virgilio, Ovidio, Séneca, Claudiano, para mencionar solo las fuentes antiguas más reiteradas. Es esta idealización renacentista la que dota a los labriegos de una desnudez y unas fuerzas heroicas, equipara a las serranas con bacantes, amazonas, hamadríadas o ninfas, a las pescadoras con nereidas, a los pescadores con Adonis y Ganimedes. Se conjuga el ideal con un naturalismo, una exclusión de lo milagroso y extraordinario, casi diríamos un materialismo de signo lucreciano que permite que de algún modo sigan siendo, sin chirriantes contradicciones, serranas, pescadoras, labriegos y pescadores. El carácter maravilloso y regocijado de lo representado depende de las sofisticadas técnicas de la representación, basadas en la imitación compuesta de los más ilustres modelos de dicción poética, antiguos, italianos, españoles, con técnica y estética no muy distantes de la de ciertos humanistas de la época ya para entonces lejana que vio resurgir la antigua Arcadia.

\section{¿Sueño de evasión o utopía?}

Evidentemente este mundo feliz es una ficción, un sueño de evasión si se quiere. Resulta más difícil considerarlo una utopía en el sentido riguroso de la palabra, 
en la medida en que a primera vista ni siquiera alusivamente tiene un cariz de propuesta política. No hay nada aquí que se parezca a lo que encontramos en la obra de Thomas More: descripción minuciosa y razonada de la organización territorial, urbanística y laboral, del régimen económico y del tipo de gobierno que sería hipotéticamente responsable de un estado de felicidad colectiva ajeno a la experiencia de los europeos y que hay que proyectar in illo tempore o en otro mundo. Sí en cambio presenta el poema tenues indicios de una temática política, en vocablos como "civil», "urbano», "político»" ${ }^{49}$, e incluso "estadista» ${ }^{50}$, que el argumento, entendido superficialmente, no parecía exigir. Es notable por lo demás la ausencia total de personajes individualizados, exactamente como en la descripción de Utopía por Hithlodaeus. No se nos habla aquí de sujetos felices, sino de una sociedad feliz, cuyos miembros tienen virtudes que no son personales sino consecuencia del mundo al que pertenecen: nadie tiene una personalidad destacable, nadie es un caso singular, todos son ejemplos de un prototipo de hombre o mujer plenamente dichoso en una sociedad que coopera con sus deseos, y excluye sin represión deseos destructivos o simplemente irrealizables.

En cambio en las más características pastorales renacentistas, incluida la Arcadia de Sannazaro, y en toda su descendencia española desde Garcilaso, cada personaje, cada pastor o pastora, es el héroe de un pequeño drama individual y está expuesto al riesgo de verse rechazado o traicionado por la persona amada o de verla morir, desdichas que ninguna felicidad colectiva puede compensar y a las que ningún discurso político puede hacer frente. Esta diferencia indica a nuestro entender que el poema de Góngora es de naturaleza política tanto o más que lírica o elegíaca, y más filosófico que sentimental.

Parece digno de observarse que los pobladores de la región recorrida por el peregrino de Góngora y los objetos de su mundo son de modo repetido calificados de «bárbaros»" . En el idioma español de los siglos XVI y XVII, este adjetivo se

49. La palabra, como todas las pertenecientes a este campo semántico, no carece de ambigüedad. "Político» puede calificar, como adjetivo, lo perteneciente a la república y a su gobierno, con matices positivos (acercándose entonces a prudente) o, al contrario, negativos: pudo emplearse en ciertos casos como equivalente a "secuaz de Maquiavelo», partidario de una anticristiana razón de Estado, etc. Pero en otros casos, la palabra se limita un calificativo más neutro de «urbanidad», «refinamiento» (de "policía»). «Político» es entonces posible antónimo de «bárbaro», incluso con sentido lingüístico: «Cuando hay dos vocablos, uno bárbaro, y otro Latino [...] dejo el nombre grosero y bárbaro y uso del más político» (Yepes (1619), II, "prólogo al lector).

50. "con gallarda civil magnificencia»; «en modestia civil real grandeza»; "acogió al huésped con urbano estilo»; "agricultura urbana»; "politico rapaz»; "politico serrano»; "politica alameda»; «ruda en esto política»; "cuya prudente disposición especuló Estadista / clarísimo ninguno».

51. A propósito del coro de las montañesas que caminan hacia la aldea, «bárbara capilla» (I, 557); de la joven que canta uno de los epitalamios, «dulce Musa, si consiente bárbaras el Parnaso moradoras» (I, 891-892): «bárbara corona» (I, 984) para el círculo de los aldeanos que presencian los juegos atléticos; «bárbaro observador, mas diligente, de las inciertas formas de la luna» (II, 408-409) para el viejo pescador. 
asociaba de modo preferente con los pobladores de América, de África y de las islas de ambos océanos, en cuanto no enteramente «reducidos» o "pacificados» por los españoles y cristianos, pacificación o reducción que por lo demás nunca podían darse por acabadas. Algunos escritores habían descrito a los americanos como gentes admirables por su inocencia (al modo de Bartolomé de las Casas) o por su amor indomable a la libertad y a la patria (al modo de Alonso de Ercilla). Sin embargo estas virtudes eran bárbaras, puesto que les faltaba la luz del Evangelio y el conocimiento de las letras. En cambio, los bárbaros de Góngora son indudablemente europeos y seguramente españoles más o menos contemporáneos.

¿Por qué motivo usa pues Góngora de este calificativo para sus villanos, un calificativo ausente, que sepamos, de la tradición arcádica? Las cualidades de cortesía, organización perfecta y sin violencia, e incluso liberalidad y magnificencia, que brillan en los pobladores de la región recorrida por el peregrino impiden pensar que la palabra "bárbaro» implique en este caso una escasa capacidad para la vida civil, y menos unas costumbres inhumanas y feroces. Claro está que estos villanos no han ido a la universidad, ni a otra escuela que a la ruda escuela del trabajo; no han tenido maestros de música, ni de pintura ni de arquitectura. Pero todo ello no supone una verdadera inferioridad puesto que hablan con la misma elocuencia inspirada que Catulo, Teócrito o Séneca, cantan como ruiseñores y como Orfeos y sirenas; y puesto que los modestos frutos de su labor artística — cabañas, redes, palomares, jardines, cuencos de boj, manteles de sayal o de lino- son de impecable elegancia precisamente por su carácter límpidamente funcional.

De todo lo cual se infiere que la condición de bárbaros, lejos de ser un obstáculo para la felicidad, es al contrario lo que los hace felices. No hay entre ellos señores ni clérigos, ni cobradores de impuestos, ni predicadores, ni comisarios de la cruzada, ni arqueros de la Santa Hermandad. O mejor dicho, se omite manifestar, incluso de modo indirecto, su presencia. De que estos villanos sean españoles y contemporáneos y por lo tanto cristianos y, más específicamente, católicos, no se hace memoria o apenas: en la aldea, la torre de lo que debe de ser la iglesia sólo se menciona como plataforma de lanzamiento para los fuegos de artificio, «sacro volcán de errante fuego»:

al pueblo llegan con la luz que el día cedió al sacro volcán de errante fuego, a la torre, de luces coronada [...] (I, 645-647)

Los coros de zagales y zagalejas que entonan el epitalamio acompañan a su casa a los novios viniendo del "vecino templo santo» (I, 845-7); la iglesia sin duda, pero en esta ambigua expresión queda resumido y en la práctica relegado a una marginalidad insignificante todo lo que en la ceremonia de boda puede remitir al ámbito del sacramento y de lo sacro cristiano. Después de «la comida prolija de pescados» un inciso indica que el viejo pescador agradece a Dios el alimento que acaban de disfrutar: 
Comieron, pues, y rudamente dadas

gracias el pescador a la divina

próvida mano [...] (II, 361-3)

Esta «divina próvida mano» bien podía ser, para los españoles de entonces, sin más problemas, la del Dios cristiano, Uno en tres Personas, en que era obligatorio creer y de que les hablaban curas y predicadores, pero nada se opone tampoco a que las dádivas que agradece el anciano procedan del Dios de los filósofos, la divinidad creadora y providente garante de la inmortalidad y que premia a los buenos y castiga a los malos, única creencia obligatoria en Utopía ${ }^{52}$.

Este dispositivo sugiere que, en el territorio privilegiado de la ficción poética, la felicidad y las virtudes más auténticas se dan en una sociedad sin señores y, lo que es más grave, sin magisterio eclesiástico y sin fe cristiana. Lo mismo pasaba por lo demás en la Utopía de More, aunque éste llegaría a convertirse en un mártir de la Iglesia católica, e incluso en un santo.

Claro que no es obligatorio tomarse al pie de la letra la indicada sugerencia. Una escapatoria muy practicable permite sustraerse a la impresión dudosa dejada por una virtud europea y moderna que prescinde de la piedad cristiana y de la presencia eclesiástica. Consiste en pensar que estamos en el terreno de una convención literaria, la convención arcádica o pastoril precisamente, que neutraliza la oposición entre verdad y mentira ${ }^{53}$ : ¿No ocurre lo mismo en la Arcadia de Sannazaro? ¿y en Garcilaso? Y en el Siglo de Oro en las selvas de Erifile de Balbuena, obra de un eclesiástico pretendiente?

Subsiste sin embargo una diferencia significativa. En las obras renacentistas de ambientación bucólica los pastores son paganos y esto significa que pertenecen inequívocamente al mundo de la literatura, irreal y fuera de la historia. En

52. El fundador y legislador de Utopía, Utopos, dejó abierta la cuestión de lo que convenía pensar de la divinidad y prohibió solamente la intolerancia y el uso de castigos y amenazas para obligar a creer esto o aquello; no obstante obligó, so pena de descrédito social, a creer en la inmortalidad del alma y en la providencia que premia a los buenos y castiga a los malos: "Itaque hanc totam rem in medio posuit, et quid credendum putaret liberum cuique reliquit, nisi quod sancte ac severe vetuit ne quis usque adeo ab humanae naturae dignitate degneret ut animas quoque interire cum corpore aut mundum temere ferri, sublata providentia, putet.» (More 1995: 222-224). Traducción o adaptación española: «así movidos de estas razones dejaron libres a cada cual el creer aquello que más le agradase. Solamente prohibieron que ninguno afirmase morir las ánimas juntamente con los cuerpos, y que el mundo se governase a caso, sin providencia divina [...]» (Medinilla y Porres 1637: fol. 42r.).

53. La neutralidad del plano estético con respecto a las creencias y a los deberes impuestos a todos por la civilización cristiana (conjugación del monoteísmo bíblico y del dualismo ontológico platónico) se basa en parte en la inmunidad de que goza el mundo pastoril convencionalmente pagano en la cultura renacentista y post-renacentista. Véase Flahault (1993: 505): «Au terme du lent processus d'effondrement du polythéisme, il n'en resta plus que les récits mythologiques et la littérature pastorale. Bien que celle-ci implique, nous le verrons, une conception de l'être humain incompatible avec le platonisme et le christianisme, elle ne fut pas rejetée. Considérée comme un patrimoine esthétique et non pas dogmatique, elle eut la chance d'échapper à la juridiction du vrai et du faux." 
la prosa tercera de la Arcadia de Sannazaro el narrador, el napolitano exilado Sincero (que por entonces aun no ha revelado su identidad), participa en los ritos celebrados en honor a Pales, diosa de los pastores, copiados de los Fastos de Ovidio. En la Égloga primera, el Nemoroso de Garcilaso reprocha a Diana que, a pesar del culto fiel que él le rendía, haya dejado morir a Elisa sin socorrerla, por puro egoísmo, por no abandonar un instante sus propios placeres: «Y tú, rústica diosa ¿¿dónde estabas? ... ¿íbate tanto en perseguir las fieras? ¿íbate tanto en un pastor dormido ?». Hay ninfas consagradas a esta misma diosa en varias églogas -empezando por la égloga segunda de Garcilaso-y novelas pastoriles. En Il pastor fido de Guarini, la tragedia que se cierne sobre los protagonistas consiste en el sacrificio anual de muchachas exigido por Cintia-Diana que hace pesar sobre Arcadia la inminencia de la peste. En la Diana de Montemayor nos encontramos con unos sátiros violadores; también aparecen sátiros, ninfas y dioses, como $\mathrm{Cu}$ pido, Mercurio o Apolo, en muchas comedias pastoriles de Lope de Vega.

En cambio los bárbaros de las Soledades no rinden culto a ninguna divinidad ni puede asomar por su mundo ninguna figura del Panteón antiguo que no sea alegórica. Su paganismo, si puede hablarse en esos términos, es inconsciente o, si se prefiere, poético y metafórico: su albergue es «templo de Pales, alquería de Flora»; ellos mismos encarnan a las divinidades, sin saberlo o sin proponérselo. Uno de los cabreros parece un "Marte semicapro» y un Pan armado, una suma pues de dos deidades del Panteón clásico. El pescador es «émulo del sagrado Nereo», por ser padre de seis bellísimas muchachas, «seis deidades bellas», un grupo de Nereidas que también son Dianas que pescan y Tetis que cazan. Himeneo, Juno, Venus, favorecen la unión de sus novios pero eso no quiere decir más de que su unión es ardiente, fiel y gozosa; un Cupido alejandrino y napolitano navegando en su concha, el nieto de la espuma, propicia su felicidad ${ }^{54}$, pero ellos no necesitan dirigirle ruegos. Es su propia vida rústica, como tal, la que por sus virtudes los eleva a la dichosa serenidad de unos dioses interpretables de modo inmediato como fuerzas que actúan en la realidad más terrenal. Se mantiene pues el texto en una ambigüedad más propia de la poesía cortesana (que diviniza a los grandes, adoptando el lenguaje del panegírico tardoantiguo) que de la modesta bucólica: hablando de ciertos hombres como de dioses ¿somos paganos o somos simplemente poetas, cultivadores de la hipérbole y del inocente sofisma?

\section{El significado político de la utópica arcadia gongorina}

Si admitiéramos una proposición política utópica en las Soledades de Góngora, esta sería paradójica por tener un contenido igualitario y por otro lado una forma críptica que parece reservar su lectura a unos pocos privilegiados. Sus con-

54. Ponce Cárdenas (2013a: 104-106). 
temporáneos, incluso los más cultos, entre quienes despertó tantos «pareceres y contradicciones», en expresión de Díaz de Rivas, lo encontraron casi tan difícil como nosotros, y sus aficionados escribieron prolijos escolios para descubrir lo que tenía en común con la más venerada tradición poética y con cuánta agudeza manejaba ese riquísimo acervo de figuras, fábulas, epítetos y conceptos.

En el fondo, no es mucho menos paradójica la Utopía comunista de More, redactada en un latín lleno de savia pese a su artificialidad, con copioso vocabulario y períodos no pocas veces largos y enrevesados. Por lo demás, un complejo sustrato filosófico, literario, teológico y político se ocultaba bajo la superficie amena del viaje maravilloso y del diálogo irónico. En las primeras ediciones se incluye un complicado aparato paratextual con cartas de varios autores. Con mayor o menor ambigüedad éstas se asocian al practical joke, al relato de viaje fantástico, pero rodeado de garantías de veracidad, en circunstancias cuya exactitud histórica es fácil de comprobar: el viaje a Flandes de Thomas More para negociar en nombre del rey de Inglaterra con el todavía adolescente Carlos de Castilla, y su encuentro con el imaginario Hytlodeus en la casa perfectamente real del joven secretario de la ciudad de Amberes Petrus Aegidius (Peter Gilles). Aegidius, uno de los prologuistas, corrobora con su testimonio la existencia del navegante y de su viaje a Utopía. Las cartas que abren el volumen en las ediciones de Basilea y París de 1517 y 1518 (y en muchas posteriores) están firmadas por Erasmo y Budeo (Guillaume Budé), dos de los eruditos de mayor fama de la Europa de entonces. Para este círculo más que selecto, y no para todos, fue concebida esta ingeniosa mistificación y las atrevidas ideas que en ella se barajaban se concibieron para alimentar sus meditaciones. No eran para todos desde luego las características chocantes de Utopía que el viajero exponía con toda tranquilidad: no sólo comunismo y divorcio sino sacerdocio de las mujeres, casamiento de los sacerdotes, institucionalidad de la eutanasia y, en un plano menos anecdótico, tesis epicúrea de que la felicidad reside en el placer.

Para que una propuesta extravagante en lenguaje esotérico merezca ser caracterizada como política se requieren ciertas condiciones. En el entorno histórico de dicha propuesta deben darse discursos más fáciles de aceptar y de entender y con objetivos más modestos que sirvan de puente entre la audacia del modelo imaginario y lo que va de veras y se estima realizable. Debe haber un ambiente, un círculo de personas, por minoritario que sea, en que las ideas de que es portador el modelo utópico u otras menos radicales pero afines a ellas sean expresadas sin tapujos y tomadas en serio. En el caso de Thomas More, este círculo, como hemos apuntado, lo formaban ciertos humanistas afines a Erasmo, de los Países Bajos, de Londres y de Oxford, de Basilea, de Venecia, de Francia, que iban a extender muy pronto sus redes en España. En estos ambientes se censuraba que los grandes propietarios de ganado ovino, nobles o eclesiásticos, expropriaran a los campesinos para producir mayores cantidades de lana destinada al jugoso negocio de la exportación; se consideraba cruel, hipócrita e ineficaz la condena a la horca de ladrones abocados a serlo por la organización perversa de las des- 
igualdades sociales; se ridiculizaba la gloria guerrera, el orgullo de la sangre, el fausto y boato y demás ideales de la nobleza. Hallamos estas tesis, formuladas con notable energía, en el libro primero de Utopía, que fue añadido en el último momento, poco antes de la publicación ${ }^{55}$. Hythlodeus las defiende — sin éxito- en una conversación cortesana, en presencia del cardenal John Morton, arzobispo de Canterbury y canciller de Inglaterra, a cuyo servicio More había oficiado de paje en su primera juventud.

En resumidas cuentas, aunque el libro del futuro canciller y mártir sea demasiado sutil y original para reducirse a ideología erasmiana, se nutre de las ideas políticas debatidas entre el maestro de Rotterdam y ciertos discípulos y aficionados suyos. Las costumbres e instituciones de Utopía, tan admiradas por Hythlodeus, son rechazadas por More al final del segundo libro en términos irónicos que hacen equívoca su desaprobación ${ }^{56}$. Existían desde luego personas (representadas por quienes intervienen en el aparato prologal, variable según las ediciones) capaces de discutir con simpatía los principios en que se basaba Utopía: supresión del dinero y de la propiedad privada y guerra puramente defensiva, nunca con fines de conquista o anexión. Sin duda esperaban de esa discusión, si no la aplicación directa y literal de esos principios, al menos la puesta en marcha de un proceso de reformas en ellos inspirado. En esa medida, el texto no es una anodina fantasía. No por casualidad se ha dado el nombre de "utopía» a una imagen que flota en un vacío sideral, en el no-lugar que prescinde de toda continuidad con el pasado y de toda concesión a la opinión común, y que por lo tanto difícilmente puede insertarse en el tiempo histórico sin destruir de golpe y con la mayor violencia todo lo existente:

Utopia vero insula, quam etiam Udepotiam apellari audio, mirifica utique sorte (si credimus) Christianos vero ritus ac germanam ipsam sapientiam publice privatimque hausisse perhibetur, intemeratamque ad hunc usque diem servasse, utpote quae tria divina instituta — hoc est bonorum malorumque inter cives aequalitatem (seu malis civilitatem numeris omnibus suis absolutam) et pacis ac tranquillitatis amorem constantem ac pertinacem, et auri argentique contemptum — consertis (ut aiunt) manibus retinet, tria (ut ita loquar) everricula omnium fraudum, imposturarum, circumscriptionum,

55. Como lo indican las citadas ediciones de Utopia y lo recuerda Emmanuelle Lacore-Martin: "On sait, grâce à des allusions très claires dans la correspondance d'Érasme, que le second livre a été composé le premier, au terme d'un long travail préparatoire comprenant lectures, prises de notes, entretiens avec d'autres humanistes, et en particulier Erasme, tandis que ce qui apparaît désormais comme le livre I d'Utopie a en fait été rédigé en 1516, l'année même de la publication..." (Lacore-Martin, 2008,124)

56. More (1995: 246): «Haec ubi Raphael recensuit, quamquam haud pauca mihi succurrebant quae in eius populi moribus legibusque perquam absurde videbantur instituta, non solum de belli gerendi ratione et rebus divinis ac religione, aliisque insuper eorum institutis, sed in eo quoque ipso maxime quod maximus totius institutionis fundamentum est, vita scilicet victuque communi sine ullo pecuniae commercio, qua una re funditus evertitur omnis nobilitas, magnificentia, splendor, maiestas, vera (ut publica est opinio) decora atque ornamenta reipublicae [...]». 
versutiarum et planicarum improbitatum. Superi suo numine facerent ut haec tria Utopianae legis capita trabalibus clavis firmae ac statae persuasionis in sensibus omnium mortalium figerentur. (Epístola de Guillaume Budé a Lupset) ${ }^{57}$

'La isla de Utopía, sin embargo, que también llaman Udepotia, parece por una suerte extraordinaria haber embebido en su vida privada y pública verdaderas costumbres cristianas y una genuina sabiduría, y haberlas conservado invioladas hasta el día de hoy. Y ello porque se ha aferrado a tres principios divinos: o sea, la igualdad de bienes y de males entre los ciudadanos (o si preferís la incondicional participación de todos en la ciudadanía); el amor constante y sin concesiones a la paz y la tranquilidad, y el desprecio del oro y de la plata. Gracias a estos principios, quedan barridas de golpe todas las formas de fraudes, imposturas, asechanzas, trampas y todo género de engaños. Que los dioses con su divino poder hagan que estos pilares de las leyes utopianas queden fijados con los clavos de una fuerte y tenaz convicción en las creencias de todos los mortales.' (traducción propia)

Ahora bien, del mismo modo que en tiempos de More y de Erasmo se agitaban ideas de reforma radical fundadas en la aspiración a restablecer al cristianismo evangélico $^{58}$, por los años en que empezaron a difundirse las Soledades, o sea a finales del ministerio o privanza del duque de Lerma, existían círculos que compartían ideas políticas a cuya luz podía tener sentido la enigmática y refinada sociedad de labradores felices imaginada por Góngora. Formaba parte de estos círculos el pensador humanista Pedro de Valencia (Zafra c.1555-Madrid 1620), que reconoció en las Soledades algo que no desmerecía de su concepto de la poesía formado por apasionadas lecturas de Homero y de Píndaro, de los trágicos y de los bucólicos griegos. Góngora se tomó gran interés en conocer la opinión de Pedro de Valencia sobre el Polifemo y las Soledades, modificó los pasajes que a éste le disgustaron y consideró una carta suya cálidamente elogiosa ${ }^{59}$ como el mejor escudo contra sus detractores. A raíz de la muerte del cronista, a quien llama «nuestro buen amigo", escribió desde Madrid a su corresponsal cordobés que España había perdido el hombre "que mejor podía oponer a los extranjeros» ${ }^{60}$. Si se tienen en cuenta los hábitos del poeta, su reserva y su escepticismo congénitos, esta gavilla de datos prueba un grado excepcional de admiración y de simpatía ${ }^{61}$.

57. More (1995: 12-14).

58. Sobre el comunismo de Utopía a la luz de la tradición cristiana de pobreza evangélica y vida comunitaria, véase Surtz (1949).

59. La carta del 6 de mayo de 1614 de que conservamos un fragmento. Véase Góngora 2000: II, 518-9.

60. En esta carta no destinada a la publicidad, dirigida a Francisco del Corral y fechada en Madrid el 14 de abril de 1620, Góngora escribía: «Nuestro buen amigo Pedro de Valencia murió el viernes pasado; helo sentido por lo que debo a nuestra nación, que ha perdido el sujeto que mayor podía ostentar y oponer a los extranjeros». Véase Góngora (1999: 350). En opinión del poeta, nadie pues mejor que Pedro de Valencia podía sostener la vacilante reputación de la cultura española en Europa. 61. Blanco, 2004. 
Pedro de Valencia pertenece a una distinguida minoría propia de la Europa del Renacimiento, la de los intelectuales laicos o clérigos seculares con formación jurídica, humanística, filosófica y teológica, comprometidos en una racionalización y moralización de la vida social y política, que esperan propiciar ejerciendo de libres preceptores o consejeros del monarca. El conocimiento del griego y la afición por el helenismo son característicos de este grupo. A él perteneció Thomas More un siglo antes, en otro país y en circunstancias distintas. Los discursos de Valencia sobre cuestiones económicas, filológicas, filosóficas, religiosas y sociales se leyeron y se copiaron, sus pareceres fueron solicitados por altas instancias de la Iglesia y del Estado y rara vez fueron objeto de censura. Sólo en 1618, cuando le quedaban menos de dos años de vida, tuvo que habérselas con una intervención inquisitorial por haber impugnado la autenticidad de los plomos del Sacromonte ${ }^{62}$. Sin embargo, sus ideas, como las del canciller inglés, presentan un sesgo radical que puede resultar asombroso. En el discurso titulado Consideraciones acerca de enfermedades y salud del reino, que su editor fecha entre 1613 y 1618, Pedro de Valencia opone tajantemente «el reino» y la «monarquía” y considera la segunda como una excrecencia parasitaria y destructiva del segundo, o, según una divertida metáfora, como una esposa bella y querida, pero cuyos caprichos insaciables arruinan a su desgraciado marido:

Fue el casamiento del Reino con la monarquía nada acertado en sí, como si un labrador y ganadero, rico de heredades y ganados, casase con una señora de alto linaje y gran presunción que con sus demasías, pompas y gastos, lo inquietase y lo fuese consumiendo [...]. Las riquezas de oro y plata causaron ociosidad y regalos, y aconteció como si a otro tal labrador le hubiese venido una muy rica herencia de las Indias, y con ella, él y sus hijos y criados se dejasen de la labranza, y se hicieran regalados galanes, holgazanes caballeros, valentones y jugadores perdidos, en fin, se empeñasen y se cargasen de deudas que ni son ya para volver al trabajo del campo y dejar de hacer mohatras, y destruirse y hundirse más y más a sabiendas, por no morir desde luego de hambre o en la cárcel o en el hospital. ${ }^{63}$

Como puede verse en este y otros muchos pasajes, Valencia estima (claro que la idea era para entonces casi un lugar común) que los metales preciosos de Indias y el dinero fácil han arruinado a España. Plantea pues que el dinero, lejos de ser el nervio de la economía, el mágico fluido que hace circular los bienes y fructificar la riqueza, los contamina de una vanidad y de una irrealidad que se traduce por

62. Valencia (1993-2012). Véase Magnier (2003) acerca de las circunstancias de la decisión inquisitorial de confiscar los papeles de Pedro de Valencia sobre los plomos del Sacromonte (al tiempo que los de todo un grupo o círculo que compartía su opinión de que estos plomos eran falsos). El parecer del humanista zafreño al respecto había sido solicitado nada menos que por el papa Paolo $\mathrm{V}$, alertado por algunos miembros de este grupo, por medio del arzobispo de Toledo, Bernardo de Sandoval y Rojas.

63. Valencia (1999: 514). 
despilfarro y miseria. El planteamiento es acorde con los principios de Utopía. Por lo demás desaprueba que, bajo ningún pretexto, se intervenga militarmente en Europa. Tiene en santo horror cualquier idea de expansión o de conquista, salvo si se trata de las «islas adyacentes», y de la costa de África, «que es la propia conquista de España». Propugna una concentración del esfuerzo de gestión y gobierno en la Península, algo que debe comenzar por una reforma agraria.

Para estas ideas, Valencia hallaba pábulo en sus lecturas y aficiones de helenista, en escritores griegos de época imperial como Plutarco y como Dión Crisóstomo (o de Prusa). De este último, a quien cita con frecuencia y de quien tradujo un discurso $^{64}$ se inspiran algunos de sus escritos más importantes y característicos: el «Discurso sobre el acrecentamiento de la labor de la tierra» y el «Discurso contra la ociosidad ${ }^{65}$, redactados entre 1607 y 1608 con ánimo de responder, según él mismo dice, a la «obligación» en que le pone su reciente nombramiento como "Coronista general» del rey. Gaspar Morocho Gayo, que editó en Gredos la obra del autor griego y que por otra parte lanzó la magna publicación en León de las obras completas de Pedro de Valencia, puso de relieve por primera vez que Dión Crisóstomo fue autor favorito y fuente privilegiada de inspiración para el humanista de Zafra. Las medidas de reforma agraria propugnadas por el antiguo sofista — que Mazon relacionó con la política seguida por Nerva y por Trajano ${ }^{66}$ - tuvieron probable incidencia en la obsesión por la reforma de la agricultura y la fijación de un precio máximo del pan que se observa en los escritos del humanista ${ }^{67}$. El concepto que éste tenía de la actividad intelectual y de las humanidades — como que se debía poner sin la menor reserva al servicio de la «república»—, no parece muy distinto del que tuvo el escritor griego - y tampoco del de Thomas More. Un discurso de Dión establece la obligación del intelectual (del filósofo) de practicar una forma de retiro invisible e interior mientras, viviendo exteriormente en el corazón de la república, asume sus obligaciones como ciudadano. Es precisamente este discurso el que eligió Valencia para vertirlo al castellano, traduciendo el término griego de «anachôresis» por «retiramiento» ${ }^{68}$. Los ochenta discursos conservados de Dión permiten reconstruir con bastante probabilidad sus opiniones sobre el imperio y su implicación en la política de su provincia (Bitinia), tanto durante

64. Valencia (2008).

65. Valencia (1994).

66. Mazon (1943).

67. Valencia (1994).

68. Valencia (2008). Véase Desideri (1978: 377): "Ad esempio il 'Sull'anacoresi', che è il più deciso attacco dioneo alla concezione, di matrice chiaramente epicurea, della filosofia intesa come perfezionamiento interiore da conseguirsi nella solitudine e nel distacco della vita sociale: qui si sottolineano anzi i pericoli impliciti nell'eccessiva disponibilità di tempo libero e di quiete. Il concetto di anacoresi, dice Dione, è estremamente equivoco, perché con la sua apparente rispettabilità serve a mascherare comportamenti che non hanno niente di rispettabili [...] L'abuso primo e più grave è certamente quello di chi si compiace di chiamare cosi la propria colpevole trascuratezza degli obblighi e dei compiti di natura politica che incombono su di lui [...]». 
su exilio en época de Domiciano como durante el período en que participó en el gobierno de Prusa, arropado por el favor imperial de Nerva y luego de Trajano ${ }^{69}$. Su ejemplo pudo alentar en Pedro de Valencia, convertido en consejero informal de Felipe III y de los altos círculos de gobierno, un sentimiento de cercanía al autor antiguo ${ }^{70}$. Esta homología de su posición de intelectual con la de Dión Crisóstomo hizo tal vez que buscara en sus ideas lo que podía aplicarse a su tiempo. María Rosa Lida de Malkiel descubrió una sorprendente semejanza entre la intriga de la Soledad segunda y la historia contada en la primera mitad del discurso VII de Dión Crisóstomo ${ }^{71}$, conocido como «El cazador de Eubea» o el «Discurso euboico». En opinión de la gran estudiosa, era muy improbable que una semejanza tan precisa fuese fortuita ${ }^{72}$. Su argumentación nos convence plenamente y más con el trasfondo que estamos evocando.

Valencia, como a su modo y en otras circunstancias More (lo mismo que Erasmo o Vives), pretende que se le dé un vuelco total a una política de gran potencia hegemónica, basada en la razón de estado. Los presupuestos de esta política, por el hecho de ser compartidos por otros príncipes y continuar una tradición, se ven por lo general como verdades de buen sentido, en la práctica indiscutibles. Romper con ellos tiene pues un componente quijotesco, o más bien utópico. Puede hablarse de utopía en la medida en que se pretende sustituir por una política social una política basada en la guerra o en una paz armada, que considera al pueblo como fuente de recursos financieros y humanos para el príncipe. La política social se propone reformar e incluso trastornar las bases de la organización del trabajo y de la propiedad y ello en el marco limitado de una nación, de un reino. El rey que desearía formar Valencia en Felipe III se acercaría al príncipe (princeps ${ }^{73}$ ) de tipo utopiano. Éste sólo se hace responsable de sus vasallos, y se propone civilizarlos y cuidar de su felicidad, creando un sistema defensivo insular y renunciando a la ambición de dirigir u orientar la política de otras tierras, a menos que éstas mismas soliciten su dirección, como sucede precisamente con los países vecinos de Utopía.

Todo lo cual se aleja desde luego de la experiencia histórica puesto que la formación del Estado moderno, el desarrollo interno de cada Estado (su capacidad de

69. Desideri (1978).

70. La afinidad estructural o la homología de posiciones (en cuanto a la relación del intelectual con el poder) que se adivina entre Pedro de Valencia y Dión de Prusa no ha sido, que sepamos, analizada. Los trabajos sobre Pedro de Valencia se han ocupado más bien de situar su pensamiento en relación con determinadas corrientes filosóficas helenísticas que retornan a finales del XVI, en especial el escepticismo y el "cinismo", visto precisamente a través de la obra de Dión. Véase Gómez Canseco (1993).

71. Este discurso, titulado «El cazador de Eubea» o el euboico, es sin duda «la obra más conocida de su autor».

72. Lida de Malkiel (1961).

73. La palabra «princeps» usada por More para denominar a la más alta autoridad de Utopía, ha sido a veces traducida por príncipe o rey, a veces por gobernador. Baker (1993) examina el problema con recomendable rigor. 
controlar a los ciudadanos y de impulsar o impedir cambios históricos que afectan a todo el tejido social) se acelera en las monarquías modernas, en la Inglaterra de Elizabeth, en la Francia de Richelieu, en la España de Lerma y de Olivares, a consecuencia dela necesidad de mantener o conquistar preponderancia frente a otros Estados. Porque quieren tener medios de intervención en el exterior para sostener la reputación de la "monarquía», los estadistas al servicio de los príncipes planean reformas internas tendentes a preservar sus reinos de la pobreza, y de su señal más obvia, la despoblación; y ello con ánimo de destruir las semillas de las rebeliones y de lograr un consenso más fácil a la hora de solicitar el «servicio» u otras imposiciones. El impulso expansionista —y en España el imperativo más modesto de mantener los territorios y la influencia adquiridos-, induciendo una presión fiscal creciente, dota a las monarquías modernas de proyección hacia el futuro y hace que contemplen estrategias a largo y medio plazo, planes de desarrollo agrícola, industrial, mercantil, naval o bancario, y examinen propuestas de reforma, aunque pocas veces consigan aplicarlas a fondo. En el caso de Espańa, circunstancias adversas y estructuras demasiado rígidas y arcaicas hicieron naufragar estrepitosamente este proceso durante el ministerio del conde-duque de Olivares.

Los profanos en esta materia tendemos a creer que el componente utópico de la política sólo pudo existir en esas primeras décadas del xvir del lado de los reformadores, fisiócratas, mercantilistas y arbitristas de toda laya a cuya ala más radical pertenecía Pedro de Valencia. Sin embargo, tampoco falta un componente utópico en el bando de quienes conciben la política como asunto que interesa al imperio, y para quienes una razón de estado digna de este nombre debe perseguir la grandeza y la gloria. Llevar a cabo ese tipo de política implica justificar y ampliar una hegemonía cuya base material y simbólica reside en un dominio concebido en términos planetarios, en una monarquía en que no se pone el sol.

Ahora bien durante el reinado de Felipe III, reinado muy calumniado del que las Soledades son un fruto singular pero característico, se planteaba en esferas de gobierno la posibilidad de alentar la exploración del Pacífico Sur con ánimo de descubrir, poblar, evangelizar, hoy diríamos colonizar, nuevas tierras, sin repetir los errores morales y políticos denunciados en América. Entre estas tierras era especialmente codiciada la Terra australis nondum cognita, el inmenso continente que los cosmógrafos antiguos situaban en el Polo Sur y que todavía indicaban, con una línea costera de pura fantasía, los atlas flamencos y holandeses que eran la última palabra del saber geográfico divulgado en tiempos de Góngora ${ }^{74}$. Entre los navegantes que emprendieron la búsqueda de este continente y la exploración de las zonas desconocidas del Pacífico, muy al sur del rumbo seguido por el galeón de Manila entre Acapulco y las Filipinas, el que más hizo hablar de sí, entonces y ahora, fue el portugués Pedro Fernándes de Queirós (hispanizado en Fernández de Quirós)

74. La intertextualidad cartográfica de las Soledades y su contemporaneidad significativa con los proyectos de Quirós han sido resaltados por Blanco (2012b: 321-329) 
que se agitó en Madrid entre 1608 y 1614, abrumando con memoriales ${ }^{75}$ al rey y a los consejos de Indias y de Estado ${ }^{76}$.

La cuestión que se ventilaba en torno a Quirós, independientemente de las cualidades y defectos del navegante portugués, era si a España le convenía invertir sus fuerzas financieras y militares, sometidas a una presión ya casi intolerable, en una gran empresa colonial en el Pacífico Sur. La respuesta fue negativa pero eso no quiere decir que no se debatió o que no merecía la pena debatirse. Para Fernández de Quirós, no cabía la menor duda de que los indios que él había visto en estas regiones australes eran dignos por sus virtudes naturales, incluida la hermosura, de que el rey de España tomara a su cargo la empresa de evangelizarlos. Por el nombre de Austrialia del Espíritu Santo que dio a la isla de las Nuevas Hébridas por él descubierta, por el de Nueva Jerusalén de la ciudad que formalmente fundó, por el protocolo que aplicó al tomar posesión de ella en nombre de la Santísima Trinidad, de la Iglesia católica, de San Francisco y su orden, de San Juan de Dios y su orden, de la orden del Espíritu santo (creada por él y objeto de burla para sus oficiales), todo ello antes de citar el nombre de Felipe III, se ve que Quirós imaginaba la nueva colonia como república teocrática ${ }^{77}$. Su programa ha sido vinculado a la tradición utópica ${ }^{78}$ no sólo por su escaso realismo, por el significado escato-

75. Según el cómputo del gran especialista del tema, Celsus Kelly, Quirós escribió al menos sesenta y cinco memoriales. El más antiguo fue dirigido en mayo de 1597 a don Luis de Velasco, virrey del Perú; el último, poco anterior a septiembre de 1614, se dirige, como la mayoría de ellos, a Felipe III. Entre estos memoriales, Quirós hizo imprimir los que compendiaban la relación de su viaje y exponían su proyecto con mayor elocuencia. El conocido como octavo memorial (23 en la numeración de Kelly, con princeps en Madrid en 1608-9), fue impreso en el original o en traducción más de cuarenta veces. Se tradujo al italiano, alemán, holandés, latín, francés e inglés. Sus primeras impresiones en lengua extranjera son las de Milán, Pandolfo Malatesta, 1611, y Augsburgo (dos veces en el mismo ańo 1611). Véase Kelly (1965: 47-50). Estos datos dan una idea del revuelo que causó, en los años en que se fraguaban las Soledades, la empresa de Quirós, dispuesto a todo para conseguir la licencia, el dinero y los hombres para dirigir una nueva expedición, consolidar su primer descubrimiento, y abrir un "nuevo nuevo mundo» austral para el Evangelio y para la monarquía espańola.

76. Para la edición más corriente y manejable de los escritos de este navegante, véase Fernández de Quirós 1986 y 1991. El «capitán» Quirós participó como piloto en la expedición de Álvaro de Mendaña (1595-1596) que descubrió las islas Marquesas y las islas de Santa Cruz. Diez años más tarde tuvo a su mando la expedición de 1605-1606, que zarpó de Callao teniendo por misión el descubrimiento de la Terra Australis, el continente que según los mapas de entonces debía cubrir una vastísima zona en torno al Polo Sur. La flota desembarcó en la mayor isla del archipiélago melanésico que se llamaría Nuevas Hébridas (y hoy Vanuatu), conocida en la actualidad por el nombre de Santo. Quirós bautizó el territorio Austrialia [sic] del Espíritu Santo y fundó una ciudad bajo el nombre de Nueva Jerusalén. Poco después, en circunstancias confusas y sospechosas, dejó la isla en la nave capitana y puso rumbo a México, arribando al puerto de La Navidad el 21 de octubre de 1606. El lugarteniente de Quirós, Luis Váez Torres, sin noticias de su capitán, siguió hacia al oeste en la nave almiranta y, tocando numerosas islas, navegó en torno a Nueva Guinea y fue el primer europeo que avistó la costa norte de Australia, antes de rendir nave en Manila. Véase Kelly (1963, 1965 y 1966). 77. Véase Quirós (1986: 256-26).

78. Gómez Tabanera (1997) relaciona a Quirós con Thomas More y cree que le debe motivos e ideas Francis Bacon en su Atlantis (1627). Ver también Luque y Mondragón, 2006. El proyecto 
lógico de estos nombres y por su afán de conciliar santidad y fabulosa riqueza, sino porque la ciudad estaba ya trazada en su mente, con detalle, antes de tener el mínimo comienzo de existencia y cuando parecía evidente que le sería imposible resistir más de unas semanas al hostigamiento de la población de la isla y al descontento de sus propios hombres. Ya pensaba en el mármol que emplearía para la construcción de su ciudad y que extraería de una cantera que creía poder abrir en unas lomas calizas que se veían en el horizonte (y todavía se ven en la isla); ya tenía claro el número de plazas y de iglesias y la disposición de las calles que saldrían de la plaza mayor ${ }^{79}$. Se percibe el peso que en el entorno de Quirós tuvo un ambiente franciscano en el que todavía alentaba el espíritu mesiánico que rodeó la empresa de Cristóbal Colón ${ }^{80}$. Eran franciscanos los aspirantes a misioneros que le acompañaron en el viaje; franciscano, el autor de una de las principales relaciones de su viaje, el padre Munilla; franciscano, Celsus Kelly, el historiador australiano que, en los años sesenta del pasado siglo, se preocupó por catalogar y editar parcialmente de modo riguroso la documentación acerca de Quirós ${ }^{81}$. Por otra parte, el capitán acariciaba la idea de que esta región del mundo reservaba inmensas riquezas a sus colonizadores pero también a sus indígenas a quienes pensaba convertir en un pueblo de grandes productores y negociantes. Además del oro y las perlas que exageraba o conjeturaba sin apenas base concreta, Quirós apostaba por la inmensa riqueza que el intenso trabajo y la evangelización traerían a unas regiones australes que describía con colores paradisíacos ${ }^{82}$ (siguiendo el ejemplo de Cristóbal Colón, con quien se identificaba). Aquellas tierras abundantes en aguas salutíferas, en hermosas y nutritivas plantas y en maderas preciosas, bañadas por frescas brisas, favorecidas por una población fuerte, inocente y agraciada, escala natural entre América y Asia, sólo necesitaban fe cristiana y dirección paternal para convertirse en un emporio marítimo, fabril y mercantil.

Sin embargo, el testimonio de los hombres que viajaron bajo el mando de Quirós en la expedición de 1605-1606 — sus resueltos antagonistas cuando quiso repetir la experiencia—, no sustentaba las halagüeñas esperanzas de una riqueza fácilmente explotable. Sólo podía afirmarse con certeza que muchos de

más desarrollado de organización ideal se encuentra en el memorial 40, de 1610, uno de los que fueron impresos en Madrid y reimpresos y traducidos, alcanzando gran difusión.

79. Ver en especial el memorial que lleva el número 40, incluido en Pinochet 1991, que numera estos memoriales de acuerdo con el cómputo de Kelly. También la carta de Diego de Prado, uno de los oficiales de alto rango de la expedición mandada por Quirós, que testificaron en contra suya, citada en Luque y Mondragón (2005: 144).

80. Milhou (1983).

81. Kelly (1965; 1963-1973; 1966).

82. Baert (1999); Luque y Mondragón (2006: 352): «En términos de proeza marítima, su mayor hazaña durante el viaje [1605-1606] fue haber llevado sus tres barcos hasta la gran bahía de una isla conocida desde entonces como Espíritu Santo [...] No obstante, en términos de su legado histórico, el mayor aporte de Fernández de Quirós fue una larga serie de memoriales en los que plasmó, post facto, una visión utópica de aquella tierra austral. De aquella nueva Arcadia.» 
los navegantes que, atraídos por el señuelo de estos hipotéticos tesoros, se asociaran a sus empresas, dejarían la vida en el intento. El llamado discurso de las navegaciones, incluido en la primera Soledad, reprueba la navegación a la vez que la concibe como un movimiento que tiene por meta las islas de las especias y el recorrido de los mares del Sur ${ }^{83}$. Por cierto es coincidencia sugerente que la muy poética expresión "isla fugitiva» que hallamos en este discurso ${ }^{84}$, tenga su equivalente en la buena prosa de Quirós, que bautizó La Fugitiva una isla que avistó y que vientos contrarios le impidieron alcanzar ${ }^{85}$. No sorprende a fin de cuentas, si leemos las Soledades en este contexto estrictamente contemporáneo de sus años de gestación, que la diatriba del serrano concluya con una solemne renuncia a la tentación que suponen los atractivos de las islas del Pacífico:

De firmes islas no la inmóvil flota en aquel mar del Alba te describo, cuyo numero, ya que no lascivo, por lo bello, agradable y por lo vario, la dulce confusión hacer podría que en los blancos estanques del Eurota la virginal desnuda montería, haciendo escollos o de mármol pario o de terso marfil sus miembros bellos, que pudo bien Acteón perderse en ellos. El bosque dividido en islas pocas fragrante productor de aquel aroma que, traducido mal por el Egito, tarde lo encomendó el Nilo a sus bocas y ellas más tarde a la gulosa Grecia, clavo no, espuela sí del apetito, que cuanto en conocello tardó Roma fue templado Catón, casta Lucrecia, quédese, amigo, en tan inciertos mares, donde, con mi hacienda, del alma se quedó la mejor prenda, cuya memoria es bueitre de pesares. (I, 481-502)

La utopía de Góngora en las Soledades cobra sentido como refutación e inversión de la utopía de Quirós o de otras análogas. Dada la publicidad que tuvieron

83. Blanco (2012a: 299-331).

84. «En esta pues fiándose atractiva / del Norte amante dura, alado roble/ no hay tormentoso cabo que no doble/ ni isla hoy a su vuelo fugitiva» (I, 393-396).

85. Sobre los nombres dados por Quirós a las tierras descubiertas, generalmente religiosos pero a veces tan poéticos como «Luna puesta», «La Fugitiva», «La Peregrina», «Gente hermosa», «Mira cómo vas", véase Baert, (1999: 92-95). 
los afanes de Quirós, aunque sólo fuera por la sensación que causaron sus memoriales impresos, atestiguada por su rápida difusión en Europa, no tiene nada de aventurado pensar que las Soledades expresaran, entre otras cosas, una postura crítica hacia el proyecto neo-colonial de Quirós. Téngase en cuenta por otra parte el sentimiento de desconfianza y hostilidad hacia este navegante que predominó en el Consejo de Indias, presidido hasta 1609 por el conde de Lemos, a quien Góngora conocía y cortejaba. La aventura neo-colonial es desaconsejable, puesto que las engañosas promesas de estas islas-ninfas, tan bellas, confusas y varias como los cuerpos de las cazadoras compañeras de Diana, no compensan los terribles peligros del viaje. Además el pragmático rechazo en virtud de un razonable cálculo de los riesgos y las ventajas va aparejado con una condena moral. El discurso de las navegaciones, que se concluye con esta solemne renuncia, da por evidente que lo que guía a los navegantes es la pasión de la codicia, lo que viene a ser ignorar o minimizar su fervor apostólico. Claro que Góngora no niega expresamente nada, y su texto hace por completo abstracción del cristianismo exactamente como si éste no existiera, no menos que lo hacía uno de sus modelos favoritos, el poeta Claudiano a comienzos del siglo v d.C., en la corte cristiana de Teodosio y de sus hijos. Pero tácitamente sí descarta las nobles motivaciones de hombres como el navegante portugués al dar por supuesto que la navegación y la guerra (dos tipos de actividad emparentados desde la antigüedad) son acciones movidas por la Codicia con mayúscula, como si no mereciera siquiera la pena discutir de otras presuntas motivaciones. A la empresa conquistadora-mesiánica, a esa guerra santa que se quiere ejecutada con los medios más suaves y pacíficos pero que es en la práctica esencialmente homicida, no opone Góngora sin embargo una simple negativa, sino otro programa no menos filosófico: el repliegue en cualquier secreto rincón de cualquier país de Europa, en una Arcadia-Utopía, un lugar en que se deja a los villanos vivir en paz, sin esquilmarlos ni pretender civilizarlos, porque de hecho estos bárbaros ya son más cultos y más "políticos» que los hombres de ciudad. De ese modo parece devolver a Europa la figura mítica conocida del «buen salvaje» proyectada en América y más aún en Oceanía (figura dieciochesca cuyos precursores van de Fracastoro y Las Casas a Montaigne). Este invento bien puede reinyectarse en una versión politizada y actualizada de la antigua Arcadia: también nosotros, españoles del campo, rústicos o provincianos, parece decir, somos buenos salvajes o bárbaros dignos del Parnaso.

\section{Conclusión}

Tanto la Arcadia de Sannazaro como la Utopía de More son obras breves pero largamente preparadas, de un gran encanto superficial y de una ambigua e inquietante profundidad. Arcadia para el napolitano exilado puede ser un refugio y un compendio de lo que la naturaleza inalterada por los hombres, tal como fue inventada y consagrada por los antiguos poetas, ofrece de más encantador y más imponente, pero es también un lugar de ruina y de duelo, una región rústica, 
pobre y lánguida, en que se agravan los males amorosos y se difunden los males políticos a los que el exilado pretendía sustraerse ${ }^{86}$. Utopía es la mejor de las repúblicas, la más humana y pacífica, la más protectora y clemente, pero también un sistema que para existir necesita proyectar hacia fuera, bajo formas extremas, las miserias de que pretende liberar a los seres humanos. De modo característico, el sistema defensivo de los utopianos es más eficaz, y en ciertos aspectos más implacable que los sistemas ofensivos de países organizados para la guerra y la conquista. Una de sus principales estrategias es usar de mercenarios extranjeros ávidos de dinero para las misiones de mayor peligro y hacer a la humanidad un buen servicio con su exterminación ${ }^{87}$. También necesita la igualitaria república de esclavos atados con cadenas de oro para matar reses y retirar basuras.

De modo comparable, la visión gongorina de su soledad agreste, en un poema breve y cuya insólita complejidad no es sólo formal, debe su encanto tal vez a una oculta duplicidad. El poema es elogio de la amable fecundidad de los campos, de los mares, de los hombres, de los ingenios sometidos a la ruda escuela de la labor cotidiana, puesto que ésta asegura la verdadera riqueza (que es pobreza sólo con respecto a los criterios corruptos de la corte) como algo que está al alcance de la mano, en cuanto se suprimen los obstáculos políticos que vedan su consecución. Pero puede leerse también como elogio de los magnates que, como el marqués de Ayamonte y el conde de Niebla, futuro duque de Medina Sidonia, saben retirarse a sus tierras, cubrir su «limpio acero» con el «sayal» y el "pellico", disfrazar de cayado su bastón de mando, y ejercer de dioses y de ninfas en medio de un inocente vulgo de serranos, labradores y pescadores, ruiseńores

86. Llegado a la mitad del libro, en la prosa VII, el narrador hasta entonces sin nombre ni figura se da a sí mismo la palabra y declara su nombre de Sincero. Cuenta entonces a la brigata o compañía pastoril, su vida que es más o menos la del mismo Sannazaro. El devenir de su familia, durante generaciones, y luego el suyo estuvieron inextricablemente mezclados a la turbulenta historia de la dinastía aragonesa. La historia concluye cuando él mismo se destierra a Arcadia, para huir de la violenta angustia causada por un amor inconfesado. Sin embargo es ahora más desgraciado que nunca, lejos de su dama y de Nápoles: "Maximamente ricordandomi in questa fervida adolescenzia dépiaceri de la deliciosa patria tra queste solitudine di Arcadia, ove, con vostra pace il dirò, non che i gioveni ne le nobili città nudriti, ma appena mi si lascia credere che le selvatiche bestie vi possano con diletto dimorare.» (Prosa VII, 18, Sannazaro, 2004).

87. Los mercenarios del pueblo de los zapoletes (que la crítica cree inventados por More pensando en los suizos) son soldados feroces y crueles, capaces de todo por dinero, y sólo leales a sus patronos mientras puedan y quieran pagarles más que sus adversarios. Los utopianos, porque desprecian el oro, tienen más oro que nadie y lo gastan inteligentemente. Por consiguiente son los amos absolutos de los zapoletes, y 'cuando la situación lo requiere, los envían a las posiciones de mayor peligro ofreciéndoles el salario más alto [...] En cuanto al número de zapoletes que perecen en la batalla, les trae sin cuidado a los utopianos, porque piensan que harían un acto meritorio barriendo de la faz de la tierra todas las heces de esa raza viciosa y repugnante': "Quos quum usus postulat, magnis impulsos pollicitationibus, maximis obiciunt periculis [...] Neque enim pensi quicquam habent quam multos ex eis perdant, rati de genere humano maximam merituros gratiam se si tota illa colluvie populi tam taetri ac nefarii orbem terrarum purgare possent.» (More (1995): 210). 
y cisnes poéticos ${ }^{88}$. El proyecto de revolución ético-política, en favor de los más humildes, podía así venir a coincidir con un sueño de paraíso aristocrático.

Combinar esta halagüeña fabulación con la robustez práctica de la utopía social, sin sacrificar las exigencias de estas postulaciones contradictorias, era una apuesta difícil, y quizá el esplendor del poema resida en la afortunada resolución de la tensión entre ambas. Resolución que concilia el refinado hedonismo de la una y el rechazo cínico de lo superfluo, característico de la otra, en nombre sin duda de la inspiración griega y de la elevada exigencia de civilización que tienen en común.

Góngora, como poeta político, expresa la tensión entre ideales contrapuestos e irrealizables en lo inmediato: como ideal para la nobleza, su transformación en una gentry rural y culta, altamente refinada y disciplinada, que practica el deporte, el mecenazgo y una magnánima filantropía; como ideal para el pueblo llano, una vida frugal y laboriosa pero también llena de amor, de fiestas, de poesía y de música en un ambiente alegremente patriarcal y comunitario, sin usureros y sin curas, sin amos y sin reyes. Tal vez el conservadurismo oligárquicoaristocrático y los gustos anarquizantes que tanto peso han tenido en la historia y en la cultura de Andalucía estén prefigurados de algún modo en el magnífico callejón sin salida que abre tal alternativa.

88. De ahí el hilo que recorre las Soledades de «menosprecio de corte», o incluso de lección de prudencia para los cortesanos en un lenguaje inspirado en la emblemática. En su compleja trama intertextual, el poema integra alusiones a los emblemas de Alciato, y de españoles como Juan de Borja y Hernando de Soto, lecciones de sabiduría e incitaciones a la meditación destinadas a los hombres de mando, nobles y magistrados. Para todo ello, véase el reciente libro de Bonilla y Tanganelli (2013). 


\section{Bibliografía}

Baert, Annie 1999, Le Paradis Terrestre, un mythe espagnol en Océanie. Les voyages de Mendaña et de Quirós 1567-1606, Paris, L'Harmattan.

BaKer, David 1993, «First Among Equals: The Utopian Prince», Moreana 30/ 115-116, pp. 33-45.

Blanco, Mercedes 2004, "Góngora y el humanista Pedro de Valencia», Góngora Hoy VI. Góngora y sus contemporáneos: de Cervantes a Quevedo, ed. J. Roses Lozano, Córdoba, Diputación de Córdoba, 2004, pp. 199-221.

—, 2012a, Góngora heroico. Las 'Soledades' y la tradición épica. Madrid, CEEH.

—, 2012b, «Ut poesis, oratio. La oficina poética de la elocuencia sacra en Hortensio Félix Paravicino", Lectura y signo. Revista de Literatura 7, pp. 29-65.

Bonilla Cerezo, Rafael (y Paolo Tanganelli) 2013, 'Soledades' ilustradas. Retablo emblemático de Góngora, Madrid, Editorial Delirio, 2013.

Borges Morán, Pedro 1995, «La inspiración americana de la Utopía de Thomas More», Mar Oceana: revista del humanismo español e iberoamericano 2, pp. 91-111.

Cañas Gallart, Cecilia 2013, La traducción de la Arcadia de Sannazaro por Jerónimo Jiménez de Urrea. Estudio y edición crítica. Tesis Universitat de Barcelona. http://diposit.ub.edu/dspace/handle/2445/43385?mode=full

Cacho Casal, Rodrigo 2007, «Góngora in Arcadia: Sannazaro and the Pastoral Mode of the Soledades», Romanic Review 98/4, pp. 435-455.

Caracciolo Aricó, Angela 1995, L'Arcadia' del Sannazaro nell'autunno dell'Umanesimo, Roma, Bulzoni.

Cave, Alfred A. 1991, "Thomas More and the New World», Albion: A Quarterly Journal Concerned with British Studies 23/2, pp. 209-229.

Cave, Terence 2011, Thomas More's Utopia in Early Modern Europe: Paratexts and Contexts, Manchester-NY, Manchester University Press.

Desideri, Paolo 1978, Dione di Prusa. Un intellettuale greco nell'impero romano, Mesina-Florencia, Casa Editrice d'Anna.

Detienne, Marcel 1970, «La cuisine de Pythagore», Archive Sociologie des Religions 29, p. 141-162.

Elvira, Muriel 2014, "L'épisode de la chasse aux faucons dans la deuxième Solitude de Góngora. Une tragédie sans pathos», e-Spania [En línea], 17 | febrero 2014: http://e-spania.revues.org/ DOI 10.4000/e-spania.23361

Espinosa, Pedro 1991, Obras en prosa, ed. F. López Estrada, Málaga, Diputación de Málaga.

Fabre-Serris, Jacqueline 2008, Rome, l'Arcadie et la mer des Argonautes. Essai sur la naissance d'une mythologie des origines en Occident, Lille, Presses du Septentrion.

Fenzi, Enrico 2009, «Limpossibile Arcadia di Iacopo Sannazaro», Iacopo Sannazaro. La cultura napolitana nell'Europa del Rinascimento, ed. Pasquele Sabbatino, Florencia, Olschki, pp. 71-95. 
Fernandez De Quirós, Pedro 1986, Descubrimiento de las regiones austriales, ed. R. Ferrando, Historia 16.

—, 1991, Memoriales de las Indias austriales, ed. O. Pinochet, Historia 16.

FLAHAUlt, François 2012-2013, «L'imaginaire pastoral: un héritage païen en milieu chrétien", L'Homme, 203-204, pp. 501-544.

Fucilla, Joseph G. 1947, «Bernardo de Balbuena’s Siglo de oro and Its Sources», Hispanic Review 15/1, pp. 101-119.

Futre Pinheiro, Marilia P., 2006 «Utopia and Utopias: a Study on a Literary Genre in Antiquity», in S. N. Byrne, E. P. Cueva, J. Alvares, Authors, Authority and Interpreters in the Ancient Novel: essays in honor of G.L. Schmeling, Groningen, Groningen University Library, pp. 4-26.

Gargano, Antonio 2002, «La égloga en Nápoles entre Sannazaro y Garcilaso» in Begoña López-Bueno y grupo PASO, La égloga, Sevilla, Universidad de Sevilla, pp. 57-76.

—, 2009, «L'Arcadia di Sannazaro in Spagna: l'Egloga II di Garcilaso tra imitatio e modello bucolico", Iacopo Sannazaro. La cultura napolitana nell'Europa del Rinascimento, ed. Pasquele Sabbatino, Florencia, Olschki, 287-296.

Gómez, Fernando 2001, Good places and Non places in Colonial Mexico. The Figure of Vasco de Quiroga (1470-1565), Lanham-Nueva York-Oxford, University Press of America.

Gómez-Tabanera, José Manuel 1995, «Sir Thomas More (1478-1535), Pedro Fernández de Quirós (1562-1615) y sir Francis Bacon (1561-1626). La forja de una utopía política en la Inglaterra del siglo XVII», XII Congreso de la Asociacion Internacional de Hispanistas, Birmingham. http://cvc.cervantes. es/literatura/aih/pdf/12/aih_12_2_032.pdf

Gómez Canseco, Luis, 1993, El humanismo después de 1600: Pedro de Valencia, Sevilla, Universidad de Sevilla.

Góngora, Luis de 1999, Epistolario completo, ed. A. Carreira, concordancias de A. Lara Pozuelo, Madrid, Biblioteca nacional de España.

—, 2000, Obras completas, ed. A. Carreira, II, Madrid, Biblioteca Castro.

Guarini, Giovanni Battista 1602, Il pastor fido, Tragicomedia pastoral de Battista Guarino, traducida de italiano en verso castellano por Christoval Suarez, Dottor en ambos derechos. En Nápoles, por Tarquinio Longo.

Jammes, Robert (ed.) 1994, Luis de Góngora, Soledades, Madrid, Castalia.

Jenkyns, Richard 1989, "Virgil and Arcadia», Journal of Roman Studies 79, pp. 26-39.

Kelly, Celsus 1963-1973, Austrialia franciscana: documentos franciscanos sobre la expedición de Pedro Fernández de Quirós al Mar del Sur (1605-6) y planes misionales sobre la conversión de los nativos de las Tierras Australes (1617-34), 6 vols. Madrid, Franciscan Historical Studies.

—, 1965, Calendar of documents: Spanish voyages in the South Pacific from Alvaro de Mendaña to Alejandro Malaspina (1567-1794), Madrid, Franciscan Historical Series. 
—, 1966, La Austrialia del Espiritu Santo. The Journal of fray Martin de Munilla (1605-6) and other documents relating to Spanish Franciscan voyages in the South Pacific, Cambridge, Cambridge University Press, 2 vols.

Kennedy, William J. 1983, Jacopo Sannazaro and the Uses of Pastoral, LondresHanovre, University Press of New England.

Lacore-Martin, Emmanuelle 2008, "L'utopie de Thomas More à Rabelais: sources antiques et réécritures», Kentron 24, pp. 123-148.

Lida De Malkiel, María Rosa 1961, «El hilo narrativo de las Soledades», Boletín de la Academia Argentina de Letras, 26, pp. 349-359.

Longeon, Claude (ed.) 1980, Le Genre pastoral en Europe du XV au XVt siècle, Saint Etienne, Université de Saint Etienne.

López Estrada, Francisco 1965, "Quevedo y la Utopia de Tomás Moro», Actas del II Congreso de la AIH. http://cvc.cervantes.es/literatura/aih/pdf/02/aih _02_1_038.pdf

—, 1980, Tomás Moro y España, Madrid, Editorial de la Universidad Complutense.

—, 1992, "Une traduction espagnole précoce de l'Utopie de Thomas More», Moreana XXIX, 111-112, pp. 15-18.

—, 1996, «La fortuna de Tomás Moro y su Utopía en la España del Siglo de Oro", La fortuna dell'Utopia di Thomas More nel dibattito politico europeo del 500, Florencia, Olschki, pp. 75-93.

Luque, Miguel (y Carlos Mondragón) 2005, «Faith Fidelity and Fancy: don Pedro Fernández de Quirós and the 'Foundation and Sustenance' of $\mathrm{La}$ Nueba Ierusalem in 1606", The Journal of Pacific History 40/2, pp. 133-48.

—, 2006, «Et in Arcadia ego. La terra australis y la visión utópica de don Pedro Fernández de Quirós», Anales del Museo de América 14, pp. 351-380.

Magnier, Grace 2003, «Pedro de Valencia, Francisco de Gurmendi and the Plomos de Granada», Al-Quantara, 24/2, pp. 409-26.

Marin, Louis 1973, «Moreana», Utopiques. Jeux d'espaces, Paris, Les éditions de minuit, pp.51-245.

Mazon, Paul 1943. «Dion de Pruse et la politique agraire de Trajan», Comptesrendus des séances de l'Académie des Inscriptions et Belles-Lettres 87/1, pp. 85-7.

Medinilla y Porres, Jerónimo Antonio de 1637, Utopia de Thomas Moro traducida de latin en Castellano por Don Gerónimo Antonio Medinilla y Porres, Caballero de la Orden de Santiago, Cavallerizo de su Magestad, Señor de las Villas de Bocos, Rozas i Remolino, Corregidor y Justicia mayor de la ciudad de Cordova y su Tierra [...] Córdoba, Salvador de Cea.

Medrano, Francisco de 2005, Diversas Rimas, Sevilla, Fundación José Manuel Lara.

Milhou, Alain 2007, Colomb et le messianisme hispanique, Montpellier, Presses Universitaires de la Méditerranée.

More, Thomas 1965, Utopia, ed. bilingüe latín-inglés, E. Surtz y J. H. Hexter, Complete Works of St. Thomas More, Yale University Press, vol. IV. 
—, 1995, Utopia, ed. bilingüe latín-inglés G. M. Logan, R. M. Adams y Clarence H. Miller, Cambridge, Cambrige University Press.

Morocho Gayo, Gaspar 1988, «Introducción general», Dión de Prusa, Discursos I-XI, Madrid, Gredos.

—, 1991, «Dión Crisóstomo y Pedro de Valencia. El ideal de la vida retirada y el Discurso del retiramiento", Los humanistas españoles y el humanismo europeo. IV Simposio de Filología clásica, Murcia, pp. 203-10.

Nelson, Eric 2006, «Utopia through Italian Eyes: Thomas More and the Critics of Civic Humanism», Renaissance Quarterly 59/4, pp. 1029-57.

Ponce Cárdenas, Jesús 2008, «El ciclo a los marqueses de Ayamonte: laus naturae y panegírico nobiliario en la poesía de Góngora», XII Jornadas de Historia de Ayamonte, ed. E. R. Arroyo Berrones, Ayamonte, Ayuntamiento de Ayamonte, 2008, pp. 107-132.

—, 2009, "Góngora y el conde de Niebla. las sutiles gestiones del mecenazgo", Criticón 106, pp. 183-219.

—, 2013a, «De nombres y deidades: claves piscatorias de la Soledad segunda», Caliope 18/3, pp. 85-125.

—, 2013b, «La imitación del discurso gongorino de la cetrería: primeras calas», in: Rodrigo Cacho y Anne Holloway (eds.), Los géneros poéticos del Siglo de Oro. Centros y periferias, Woodbridge, Tamesis Books, 2013, pp. 171-194.

PrÉvost, André 1978, L'Utopie de Thomas More, présentation, texte original, apparat critique, exégèse, traduction et notes. Paris, Mame.

Reyes Cano, Rogelio 1973, La Arcadia de Sannazaro en España, Sevilla, Editorial Católica Española.

Rojas Garcidueñas, José 1958, Bernardo de Balbuena: la vida y la obra, MexiCo, UNAM.

SACCONE, Eduardo 1974, «L'Arcadia: storia e delineamento d'une struttura», Il «soggetto» del «Furioso» e altri saggi tra Quattro e Cinquecento, Nápoles, Liguori, pp. 9-69.

SannaZaro, Iacopo 2004, Arcadia. L'Arcadie, ed. F. Erspamer, introd. y notas G. Marino, prefacio Y. Bonnefoy, París, Les Belles Lettres.

—, 2009, Latin Poetry, trad. Michael C.J. Putnam, Cambridge Mss/ Londres, The I Tatti Renaissance Library/ Harvard University Press.

—, 2013, Arcadia, ed. C. Vecce, Roma, Carrocci.

SNELl, Bruno 1945, "Arkadia: die Entdeckung einer geistigen Landschaft», Antike und Abendland: Beiträge zum Verständnis der Griechen und Römer und ihres Nachlebens, Hamburgo, I, pp. 26-41.

Steintrager, James 1969, «Plato and More's Utopia», Social Research 36/3, pp. 353-72.

Surtz, Edward (S.J.) 1949, «Thomas More and Communism», PMLA 64/3, pp. 549-564.

—, 1957, The Praise of Pleasure. Philosophy, Education and Communism in More's 'Utopia', Cambridge Mass., Harvard University press. 
Suárez de Figueroa, Cristóbal, 2006, El Pastor fido de Battista Guarini, Nápoles 1602 y Valencia 1609, textos preparados por E. Suárez Figaredo. http://users.ipfw.edu/jehle/cervante/othertxts/Suarez_Figaredo_ PastorFido_02y09.PDF

Tateo, Francesco 1993, «La Arcadia en España», «Introducción» a Arcadia de Sannazaro, Madrid, Cátedra, pp. 38-46.

Torraca, Francesco 1928, "Gli imitatori stranieri di Jacopo Sannazaro», Scritti vari, Milán- Génova, Società editrice «Dante Alighieri», pp. 109-54.

Valencia, Pedro de 1993-2012, Obras Completas, dir. G. Morocho Gayo (y Jesús María Nieto Ibáńez), León, Universidad de León, (hasta el volumen X)

—, 1994, «Discurso sobre el acrecentamiento de la labor de la tierra. Madrid 1607» y "Discurso sobre la ociosidad. Madrid, 6 de enero de 1608», IV/1. Escritos sociales. I Escritos económicos, ed. R. Rodríguez Cañal, con estudio introductorio de P. Paradinas Fuentes, pp. 137-173.

—, 1999, "Consideraciones acerca de enfermedades y salud del reino" Obras completas. IV/2. Escritos sociales. 2. Escritos politicos, ed. Rafael González Cañal, León, Universidad de León, 1999, pp. 499-527.

—, 2008, «Oración o discurso de Dion Crisóstomo, que se intitula Perianachoreseos, esto es, Del Retiramiento. Traducida de Griego», ed. S. Fernández López, estudio y comentario de J.M. Nieto Ibánez, Obras completas X. Traducciones, León, Universidad de León, pp. 171-202.

Vecce, Carlo 2013, «Introduzione» a Iacopo Sannazaro, Arcadia, ed. C. Vecce, Nápoles, Carocci, pp. 9-53.

White, Thomas I. 1976, "Aristotle and Utopia», Renaissance Quarterly 29/ 4, pp. 635-675.

WiniarczyK, Marek 2011, Die Hellenistischen Utopien, Boston/ Berlin, De Gruyter.

Wooden, Warren W. 1979, «Utopia and Arcadia: An Approach to More’s Utopia», College Literature 6/1, pp. 30-40.

Yepes, Antonio de, 1609, Corónica general de la Orden de San Benito, Irache, Matías Mares. 
